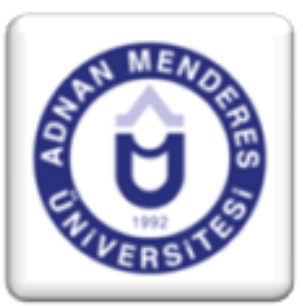

\title{
Kemer-Edremid (Burhaniye) Kazâsı ve Osmanlı Donanmasına Yaptığı Katkılar: Malzeme, Personel ve Gemi İnşâ Tezgâhı
}

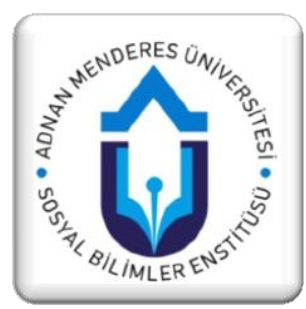

Evren GÖKÇE ${ }^{1}$

\section{Özet}

Osmanlı İmparatorluğu üç kıtaya yayılan kara topraklarını çevreleyen denizlerde kuruluşundan itibâren teşkîl ettiği donanmasıyla asırlar boyunca faaliyet göstermişti. Böylesine geniş bir alanda görev yapan Osmanlı donanmasının eksiklerinin giderilmesi, külfetli, ancak her sene yerine getirilmesi gereken bir zorunluluktu. Bu nedenle devlet, bazı çözümler geliştirmişti. Bu çözümlerden birisi de ocaklık sistemi olarak adlandırılan yöntemdi. Deniz kuvvetleri için gerekli olan malzeme ve personelin imparatorluğun belirli yerlerinden sağlandığı bu yöntem kapsamında halk, resmî talepleri karşılamakla mükellefti. Osmanlı Donanması için malzeme ve personel tedarik eden yerlerden birisi de Karesi Sancağı'ydı. Sancağın Edremit Körfezi'nde yer alan kazâlarından birisi olan Kemer-Edremid (Burhaniye), ocaklık sistemi uyarınca donanmaya hizmet vermekteydi. Bu bağlanmda, Kazdağları'na yakın bir coğrafi konuma sahip olan kazâ, donanma için başta gemi yapımının ana maddesi olan kereste olmak üzere, güherçile ve katran gibi malzemelerle birlikte, askerî ve teknik personel temîn etmekteydi. Ayrıca, bünyesinde çeşitli sınıflarda gemilerin inşâ edildiği bir tezgâha sahipti. İncelememizde Kemer-Edremid kazâsının başta kereste olmak üzere Osmanlı donanmasına yaptığı katkılar hakkında, arşiv belgeleri ve ikincil kaynaklardan elde edilen bilgilere dayanarak değerlendirmeler yapılmıştır.

Anahtar Kelimeler: Osmanlı İmparatorluğu, Donanma, Kereste, Güherçile, Kemer-Edremid (Burhaniye)

\section{Kemer-Edremid (Burhaniye) District and It's Contribution to Ottoman Naval Forces: Equipment, Staff and Shipbuilding Yard}

\begin{abstract}
Ottoman Empire had actived with it's navy that organized as from establishment of state in the seas which surrounded spread lands of the emporship to three continent over the centuries. To fullfill and renewal of neccesity of Ottoman navy forces which employed in such a large area, was a obligatory which burden to finance but need to be renewed every year. Consequently, Ottoman Empire had developed some resolitions for to meet the this taxs. The process which called ocaklık system was one of this resolitions. Within this process, public of emporship obligored in proceed demands made by the state which material and staff neccesary for navy obtained from emporships different region. Sandjak of Karesi was one of the regions that preparing material and staff for Ottoman navy. Kemer-Edremid district that one of the settlements of the Sandjak of Karesi, had been serving to Ottoman Navy as required the ocaklık system. In this context the Kemer-Edremid district that close to the Kaz Mountains, with mariner and tecnical staff, had firstly been suplying the timber which basic element of ship building and materials like niter and pitch. Add to this, it was including a loom that building in different type ships. In this study, based on to Ottoman archive documents and subordinate sources, evalitions made about Kemer-Edremid's contributions to Ottoman navy firstly timber and other additions.
\end{abstract}

Keywords: Ottoman Empire, Navy, Timber, Niter, Kemer-Edremid (Burhaniye)

\footnotetext{
${ }^{1}$ Süleyman Demirel Üniversitesi Sosyal Bilimler Enstitüsü, Yakınçağ Anabilim Dalı Doktora Öğrencisi.
} 


\section{Giriş}

\subsection{Karesi Sancağı ve Kemer-Edremid Kazâsı}

Selçukluların tarih sahnesinden çekilmesinden sonra Batı Anadolu'da kurulan önemli beyliklerden birisi de Karesi veya Karesioğulları Beyliği adıyla antik Mysia bölgesine hakîm olan Türk beyliğidir. Malazgirt savaşından sonra Anadolu'ya giren yoğun Türkmen kitleleri çeşitli bölgelere yayılarak Bizans toprakları üzerinde yeni yerleşimler teşkil edip Anadolu Selçuklu Devleti'nin idaresi altında yaşamaya başlamışlardı. 1243 tarihinde Moğollar karşısında yaşanan Kösedağ yenilgisinden sonra Anadolu Selçuklu Devleti'nin otoritesini kaybetmesiyle birlikte, Anadolu'nun farklı yerlerindeki bey ve komutanlar kendilerine bağlı bölgelerde yeni siyasî teşekküller tesis etmeye başlamışlardı. Sultan II. Mesud'un emirlerinden birisi olan Karası Bey ( Karesi Bey) babası Kalem Bey ile birlikte Bizans İmparatorluğu'nun zayıflığından yararlanarak Çanakkale'ye kadar bugünkü Balıkesir ve civarını ele geçirdikten sonra muhtemelen Germiyanoğulları'nın desteği ile XIII. yüzyılın başlarında (1300-1308) arasında bağımsızlığını ilân etmişti. (Öden, 1999: s.19-20) Belli bir süre bölgeyi idare eden ve Bizanslılar'la mücadele eden Karesioğulları'nın hakimiyeti uzun sürmemiş, güneye doğru genişlemeye başlayan komşu Osmanlı Beyliği, Karesioğulları idaresine son vererek Balıkesir, Çanakkale ve civarını topraklarına katmıştı.

Osmanlı sınırlarına erken bir tarihte katılan Karesi toprakları, beyliğin ikinci idarecisi Orhan Bey zamanında zaptedilmeye başlanmıştı. 1345 yılında Balıkesir, Manyas, Edincik ve Kapıdağı havalisi Osmanlılar tarafından fethedildikten kısa bir süre sonra Truva ve Edremid körfezi havalîsinde kalan Karesi idaresi bir müddet daha tutunabilse de, I. Murad zamanında beylik tamamen ilhâk olunmuştu. Karesi bölgesinin Marmara sahillerinin (Erdek-Kapıdağı) elde edilmesi Osmanlıların Rumeli'ne geçmesi için oldukça faydalı bir gelişme sayılmaktadır. (Uzunçarşılı: s.123-124.) Bu gelişme aynı zamanda Türk denizcilik tarihinin önemli aşamalarından birisi olarak kabul edilmektedir. Fetihten sonra ismi değiştirilmeyerek Karesi Sancağı adıyla Osmanlı idarî sistemine dahil edilen yöre, yaklaşık 500 yıl boyunca impratorluğun Anadolu Eyâleti'ne bağlı kalmıştır. Balıkesir ile birlikte, Bigadiç, Bergama, Balya, Başgelembe, Kemer-Edremid (Burhaniye), Edremid, Fesligan, Kozak, Karacalar, Ayazmend, Fırt -Şamlı, (Fart maa Şamî) ve Aydıncık kazâları, sancağın idarî birimlerini teşkîl etmekteydi. Bu kazâlarla birlikte 1786 tarihinde Ayvalık, Karesi Sancağı sınırlarına dahîl edilmiştir. (Sevim-Yücel, 1989: s.265-266)

Günümüzde, Balıkesir ilinin Edremit körfezinde yer alan ilçelerinden birisi olan Burhâniye ise Türk idaresinin başlangıcından XIX. yüzyılın sonlarına kadar Kemer veyâ Kemer-Edremid adlarıyla anılmıştır.1888 tarihli Karesi Vilâyetine Mahsus Salnâme’ye göre Kemer kasabası bu tarihte denize yarım saat uzaklıkta bulunmakta, 40 karye, 6 mahalle ve 2979 hâneden ibaret olup, bünyesinde 43 camî ile birlikte, 38 mektep, 3 medrese, 3 kilise ve 2 hamam ihtivâ etmekteydi. (Karesi Vilâyetine Mahsus Salnâme, 1305: s.117-118) Osmanlı coğrafya sözlükleri arasında en bilinenlerden birisi olan Kamûs'ul-Alâm'da Kemer-Edremid adıyla zikredilen kazâ, Edremit körfezi sahilinde, doğusunda Balıkesir, batısında Edremit körfezi, güneydoğudan Ayvalık, güneyde ise Aydın vilâyetiyle (İzmir) ile çevrili ve arazi açısından verimli bir yer olarak nitelendirilmektedir. Bu kaynaktaki verilere göre, Balıkesir'in $75 \mathrm{~km}$. batısı, Ayvalığın $30 \mathrm{~km}$. kuzeydoğusunda konumlanan Kemer-Edremid, Edremit körfezinden 2 km., körfezin iskelesi olan Akçay iskelesinden ise 5 . km uzaklıktayd1. 6 mahallesiyle birlikte 5 camîi, 1 medrese, 1 rüşdîye, birkaç sıbyan mektebi, 1 kilise, 4 han ve 160 adet dükkânı mevcuttu. Kereste, palamut ve meyve ihracatı icrâ edilen ekonomik faaliyetler arasındaydı. Aynı tarihlerdeki bir başka coğrafya eserinde ise Kemer'in Hüdavendigâr vilâyeti sınırlarındaki Karesi'ye bağlı Burhaniye kazâsının merkezi olduğu, Edremid'in iki saat kadar doğusunda yer aldığı ve Kemer-Edremid ismiyle tanındığı bilgileri verilmektedir. (Şemseddin Samî, 1314: s.3888; Ali Cevâd, 1313: s.680.)

Fransız araştırmacı Vital Cuinet 'in XIX. yüzyılın sonlarına ait olan eserine göre kazâ kuzeyden körfez ve Edremit, doğudan Balıkesir, güneyden İzmir, batıda ise Ayvalık kazası ve yine Edremit körfezi ile çevrilidir. Nahiyesi olmamakla birlikte 41 köye sahiptir. Cuinet, kazânın merkezini teşkîl eden Kemer-Edremid'i Edremit körfezinin girişinde kıyıdan $2 \mathrm{~km}$. uzak küçük bir kasaba olarak nitelendirir. Konum olarak Akçay iskelesinin $5 \mathrm{~km}$. güneyinde, Ayvalığın $30 \mathrm{~km}$. kuzeydoğusunda, Edremit'in $10 \mathrm{~km}$. güneydoğusunda, sancak merkezi Balıkesir'in ise $85 \mathrm{~km}$. batısında kalmaktadır. Cuinet aynı zamanda Şemseddin Samî gibi 
Kemer-Edremid'de 4 Han ve 160 dükkân bulunduğunu belirtmektedir.(Cuinet, 2001: s.210-211; Cuinet'in kazâ hakkında eserine aldığı verilerin bilhasa Kamûs'ul-Alâm'dakilerle benzerliği dikkat çekmektedir.)

Kemer-Edremid hakkında Cuinet ile yakın tarihlerde bilgi veren diğer bir eser Dr. Şerafeddin Mağmumî’ye aittir. İttihat ve Terakkî Cemiyeti'nin kurucularından olan Mağmumî, XIX. yüzyılın sonlarında kolerayla mücadele maksadıyla müfettişlikle görevlendirilince Anadolu ve Suriye'de birçok yeri görme fisatı elde etmiş, daha sonra bu yerler hakkındaki gözlemlerini kitap haline getirmiştir. 10 Eylül 1894 salı gününden başlayarak 4,5 ay müddetle yaptığ 1 bir gezide uğradığı yerler arasında Bursa, Beyce, Mihalıç, Mudanya, Uluabad, Bandırma, Erdek, Balıkesir, Edremit'le birlikte Kemer Edremid'de (eserde Kemer adıyla zikredilmektedir) bulunmaktadır. (Polat, 2010: s.20-21) Şerafeddin Mağmumî, Kemer kasabasının Edremit' in güneybatısında bir kazâ merkezi olduğunu, bin hanesi ve beşbini aşkın nüfusu bulunduğunu ifade etmektedir. Mağmumî’ye göre kazâ birbirlerine paralel olarak uzanan üç sokaktan ibaret, dar ve uzunca bir yerleşim birimidir. Kasabanın ortasında ve cadde üzerinde bulunan geniş kubbeli bir camiinin yanında, birkaç mescîd, ve medrese, bir kilise ve kaymakam tarafindan yaptırılan bir telgrafhâneye sahiptir. Sokaklar Edremit'e nazaran gayet temiz olup çoğu balıksırtı kaldırımla döşelidir. En önemli ticari mallar zeytinyağı ve palamuttur. Ayrıca çok miktarda koyun mevcuttur. (Polat, 2010: s.150-151)

\section{Osmanlı İmparatorluğunda Donanma İhtiyâçlarının Temîni 2.1 Malzeme ve Personel}

Birbirinden farklı dil, din ve 1rklara sahip halkların yaşadığı geniş bir coğrafyaya hükmeden Osmanlı İmparatorluğu, her devlet gibi yönettiği kitlelerden çeşitli isim ve miktarlarda vergiler tahsil ediyordu. Bazıları olağan bir şekilde, bazıları ise olağanüstü dönemlerde alınan bu vergilerin yanında (Osmanlı devleti ve halktan aldığı vergiler için Çağatay, 1947: s.483-511; Tabakoğlu, 2009.) devlet, sınırları dahilindeki bölgelerden potansiyellerine göre bazı hizmet ve yükümlülükler talep etmekteydi. Başkent iâşesinin karşılanmasından, ordunun geçeceği yolların düzeltilmesine, asayiş ve emniyetin sağlanması için muhafâza hizmetinde bulunmaya kadar (Örneğin Osmanlı topraklarında sahillerin korunması amacıyla askerler ve ahalî tarafından yerine getirilen ve kıyı nöbeti adı verilen bir hizmet için Özdemir, 2008: s.187-210) farklı şekillerde yerine getirilen bu yükümlülüklerin yöneldiği resmî kurumlardan birisi de Osmanlı donanması idi. Savaşlar nedeniyle sürekli mühimmât, malzeme, iâşe ve personel gibi gereksinimleri ortaya çıan ordunun yanı sıra, üç kıtaya yayılan denizlerde aynı sorunlarla uğraşan donanma da devlet hazînesine maddî açıdan masraf getiren birçok ihtiyaca sahipti. Bu yükümlülüklerle başetmek, vergi ve hizmetlerin karşılanabilmesini sağlamak için, devletin geliştirdiği metodlardan birisi de ocaklık sistemi olarak anılan yöntemdi.

Malî bir kavram olan ocaklık, genel anlamda kale muhâfızlarının, şehirlerde vazife yapan yerli neferlerinin ulûfelerine ( üç ayda bir alınan maâş) veya tersâne masraflarına karşılık olarak tahsis edilen öşür veya örfî gelirleri betimleyen bir tabirdir. Diğer bir deyişle devletin bir kısım giderlerinin karşılanması için bazı gelir kaynaklarının ayrılmasıdır. Bu gelir ve hizmetler sadece tersâne, yani donanma masrafları için tahsîs edilirse tersâne ocakl $\breve{g} l$ adıyla anılmaktaydı. Osmanlı tersânelerinde icrâ edilen en mühim faaliyet olan gemi yapımı kapsamında gereken malzemeler için bazı ihtiyaç bölgeleri ortaya çıkmıştı ki, bunlar da ocaklık bölgeleri olarak adlandırılmaktaydı. Ocaklık hizmeti esâsında ödenmek zorunda olunan vergi karşılığında yapılmakta, tersâne için lüzûmlu malzemeler, en fazla miktarda bulunduğu, üretildiği bölgeden ve üreticilerinden avârnz vergileri karşılığında alınmaktaydı. (Pakalın, 1993: s.712-713; Ertuğ, 2001: s.22; Bostan, 2003: s.101; Kılıç, 2007: s.317)

Osmanlı Devleti'nin kuruluşundan kısa bir süre sonra gelişmeye başlayan deniz kuvvetleri için dönüm noktalarından birisi daha önce de vurgulandığı gibi Karesi Beyliği'nin fethi olmuştu. Osmanlıların Karesi topraklarını ele geçirmeleri bir donanmaya sahip olmalarını sağladığı gibi Rumeli'de yayılmalarının ve fütühât yapmalarının önünü açmıştı. Bu hususta bilhassa Karesi hizmetinde bulunan Ece Bey, Evrenos Gazî, ve Hacı İlbeyi gibi komutanların katkısı büyüktü. (Uzunçarşıll, 1988: s.389; İnalcık, 2009: s.46-47; Batı Anadolu Beyliklerinin Osmanlı denizciliğine katkıları için İnalcık, 1987: s.309-341.) Osmanlı denizciliğinin gelişimi açısından ikinci dönüm noktası ise Fatih Sultan Mehmed'in tahta geçmesi sayılabilir. Fatih'in saltânatı esnâsında bir imparatorluk kimliği kazanan devlet, İstanbul, İzmit, Gemlik, Çanakkale, Mudanya, 
Karabiga, İzmir, Foça, Kuşadası, Midilli, Selanik, Rodos ve Sakız gibi yerlerde tersâne ve tezgâhlar inşâ etmişti. (Türkiye Denizcilik İşletmeleri Kültür Yayınları, 1994: s.100)

Osmanlı tersâne ve tezgâhlarında inşâ edilecek gemiler başta olmak üzere, gereken malzemeler, yapım esnasında görevlendirilecek personel ve Donanmây-1 Hümâyun ile sefere çıkacak askerler gibi birçok ihtiyaç yukarıda vurgulandığ 1 gibi ocaklık sistemiyle ocaklık bölgesi olarak belirlenen yerlerden tedarik edilmekte idi. Donanma için gereken en temel malzemeler arasında kereste, sütun, seren, funda, işlenmemiş demir (demîr-i ahen) çivi, kurşun, katran, zift, yağ (revgân) boya, reçine, balmumu, kendir, resen, ispavlu ve üstüpü gibi malzemeler mevcuttu. Gemilerin techizi için ise, kürek, lenger, pusula, fanus, kirpas, boğasi, tafta, keneviçe, çuka, yelken dikiş iğnesi, makara dili gibi malzelemer gerekiyordu. Savaşlarda kullanılan malzemeler arasında ise başta barut, top, yuvarlak ve ok ve yay gibi silâhlar gelmekte idi. (Uzunçarşıl1, 1988: s.446; Bostan, 2003: s.102-178 aras1)

Donanma hizmetinde istihdâm amacıyla asker, personel ve kalifiye elemanlar da kısmen taşradan tedârik edilmekteydi. Bunlar arasında bilhassa kalyoncu neferleri ön plana çıkmaktadır.1093/1628 tarihinde teşkîl edilen kalyoncu sınıfı buharlı gemilerin icâdına kadar donanma saflarında istihdam edilmiştir. Kalyonlarda hizmet eden bu askerlere bulundukları gemiye nisbeten kalyoncu ismi verildiği gibi Kasımpaşa meydanında yapılan kışlaya Kalyoncu Kışlası adı verilmişti. Kalyoncular lüzum görüldügüü zaman hizmete girip, donanmanın dönüşünden sonra memleketlerine geri giderler, görevde bulundukları esnâda kendilerine maâş alırlardı. İmparatorluk'ta genel olarak Çekmece'den Edirne'ye kadar olan yerlerden, Çanakkale mıntıkasından, Batı Anadolu kazâlarından ve adalardan kalyoncu neferleri celbediliyordu. 1823'te Sultan II.Mahmud'un saltanâtı esnâsında kalyoncu sınıfı lağv olunarak yerlerine tersâne tüfekçileri adıyla yeni bir askerî birlik kurulmuştu (Pakalın, 1993: s.154; Uzunçarş111, 1988:485-486)

Taşradan deniz kuvvetlerine gönderilen askerler arasında muharip personelin yanı sıra diğer hizmetleri yerine getirecek yardımcı sınıflar ve çeşitli işlerde görev yapacak kalifiye elemanlar da mevcuttu. Bu tip vazife sahipleri arasında gabyar adlı yardımcı hizmet sınıfını incelememizle bağlantılı olması dolayısıyla örnek verebiliriz. Gabyarlar gemi serenleri ile yelkenlere bakan ve yelkenleri açma ve muhafaza ederek düzenlerini sağlamakla vazifeli olan bahriye personeliydiler.1820'lerde vukû bulan Rum isyanı sonrasında Osmanlı gemilerinde levendlik, marnarlık ve gabyarlık gibi hizmetlerde istihdam edilen Rumların yerine müslümanların alınması kararlaştırılmıştı. 1827 Eylül tarihinde çıkarılan Tersane Nizamnâmesi'yle de Rum gabyar sınıfi tamamen lağvedilerek, Beyrut, Sayda, Akka, Remle ve Gazze sahillerinden müslüman bekar gençlerden olmak üzere 1000 nefer gabyar ve marnelin istihdâm edilmesine karar verilmişti. (Uzunçarş1l1, 1988: 487-488) Bu yardımcı sınıflarla birlikte, sanatkâr miktârının gemi inşâsı sırasında yeterli gelmediği zamanlarda halk arasından ücretle kalifiye personel tedarik ediliyordu. Bu maksatla alım yapılacak bölgelere sorumlu çavuşlar yollanarak marangoz, burgucu, haddad (demirci) gibi sanatkârlar toplanıyordu. Kalifiye personellerden gemi inşaatında asıl hizmeti geçenler özellikle marangozlar ve burgucular idi. Bilhassa sefer senelerinde bunlara ihtiyaç duyulmaktayd1.(Bostan, 2003: s.71)

\subsection{Kereste}

İmparartorluğun farklı bölgelerinden tedârik edilen malzeme ve personel dışında hiç şüphesiz donanmanın en önemli gereksinimi keresteydi. (Bostan'a göre, gemi inşâatlarının ana malzemesi olan kereste, inşâ faaliyetlerinin her zaman devâm etmesi ve bilhassa sefer senelerinde artması nedeniyle mühimmât ihtiyacında ilk sırayı almış, tedârik hususu Tersane-i Amîre'nin en önemli meselelerinden birisi olmuştu. Bostan, 2003: s.102) Osmanlı donanmasında XIX. yüzyılın ikinci yarısında demirin önem kazanmasına kadar ana yapım malzemesi ahşaptı. Ahşap malzemeler ise doğal olarak keresteden elde ediliyordu. Kullanılacak kerestenin boyutu inşâ edilecek gemiye göre değişmekteydi. Bir gemide gemi direği, saha-alan (güverte), taban tahta kaplamas1 (planks), gemi omurgas1, dirsek, gemi bordas1, dümen sap1, su dolab1 gibi yerlerde kereste kullanılmaktaydı. Bu şekilde inşâ edilen Osmanlı gemileri Avrupa'da sağlamlıkları ile tanınıyordu. İngiliz Seyyâh Pococke'un gözlemlerine göre, Midilli'de yapılan Osmanlı gemilerinin en büyük özellikleri son derece hafif olmaları ve 10-12 yıllık süre zarfında dayanmalarıydı. Bu süre Avrupa'daki gemilerden daha uzundu. (Zorlu, 2008: s.16,18; Payzın, 2008: s.95-96) 
Kereste ve diğer malzemelerin elde edildiği ormanlar devlet tarafından bir sınıflandırmaya tabi tutulmuştu. Buna göre ağaç popülasyonu barındıran yerler, mülk ormanlar, mülk korular, mülk bahçeler, mülk ağaçlı bölgeler, vakıf ormanlar, ve mîrî korular, mîrî ormanlar, mîrî bataklıklar olmak üzere çeșitli kategorilere ayrılmaktaydı. Mîrî ormanlar büyük ölçüde devlet gereksinimleri ile hanedan mensupları için ayrılmış ormanlardı. Bu kategoride cibâl-i mübahâ denilen ve devlet tarafından reayanın kereste, yakacak ve mimarî ihtiyacına ayrılmış, genellikle iskele ve tersanelere uzak olan ormanlar da yer almaktaydı. Ayrıca bazı orman, koru ve bataklıklar da çevresinde bulunan köylerin koruma ve yetiştirme hizmetleri karşılığında yararlanma hakkına sahip olduğu ahali-i kazâya merbût ormanlar olarak belirlenmişti. (Koç, 2000: s.142143)

Devletin ihtiyaçlarının karşılanması için kesilen keresteler mîrî ormanlardan sağlanıyor ve ocaklık sistemine göre tedârik ediliyordu. Donanma için kereste, gemi direği, kürek ve funda ağacı gibi ihtiyaçlar söz konusu olduğunda durum Tersane Emîni'ne bağlı olan Kereste Emîni'ne bildirilmekte, Kereste Emîni'de alımın yapılacağı yöredeki görevlilerle birlikte en kısa sürede belirlenen miktarı sağlamaya çalışmakta idi. Kereste elde edilen başlıca ağaçlar meşe, çam, karaağaç, kestane, ceviz, şimşir, ıhlamur ve çınar ağaçları idi. Tersâneler de genellikle taşıma olanaklarının elverişli olduğu yerlerde kurulduğundan tersane olan her yerde büyük ormanlar bulunuyordu. Bu ormanlardan ayrıca Tophâne ve Baruthâne gibi diğer devlet kurumlarında odun kömürü olarak kullanılması maksadıyla meşe, kestane, kayın, ladin ve köknar tedârik ediyordu. (Koç, 2000: s.146-147.) XVIII. yüzyılın sonlarına kadar Osmanlı donanmasının kereste sağladığı yerler arasında Kazdağları ve çevresindeki kazâlar ile birlikte,Midilli, Canik, Taşoz, Meğri, Rumeli, Rodos, Biga, İznikmid, Kidros, Cide, Misivri, Ahyolu, Segen, Ayna Adası, Gemlik, Domaniç, Gökabad, Gümülcüne, Bolu, Mudurnu, Abâd Yaylası, Elmacık Dağı, Sarıot Dağı, Seferîhsar, Mihalıççı, Günyüzü, Gökçedağ, Beypazarı, Tuzla, Ayvalık, Karahisâr, Kurupazarı, Kozak, Soma, Kırkağaç, Akyazı, Darıçayrı, Sarıçayır, Bigadiç gibi yerler mevcuttu. (Zorlu, 2008: s.18)

III. Selim devrinde 1804 yılında çıkarılan bir kanunnâme ile tersâne için satın alınan kereste ve diğer malzemelerin fiyat ve miktarlarını içeren teklif Umur-1 Bahrîye Nâzırı tarafından mühürlü bir takrîrle Bâb-1 Alî'ye sunulduktan sonra ödeme emrinin verilmesi ile tutarlan Tersâne-i Amîre'den ödenecekti. Bununla birlikte ocaklık mahallerinden bahrîye personeline verilen zahirelerin alım ve denetimiyle, peksimet hazırlanması gibi hususlar da nâzıra tevdî edilmişti. ( Gencer: 2001: s.75-76)

Cevdet Paşa, tarihinde devletin kereste kesim emri verdiği mevsimin sonbahar olduğunu ifade etmekte, 1820 senesi Eylül ayında kereste kesimi emri verilerek beylik gemilerin yapımına başlandığını belirtmektedir. ("İ̧̧bu (12) 36 sene-i hicrîyyesi muharreminin gurresi 1820 seney-i milâdisi Eylül-i rumîsinin yirmi yedinci gününe tesâdüf idüb, kereste kesmek mevsimi olduğuna mebnî hemân canîb-i mîrî içün ka't ve nakline ve müceddeden beylik sefineler inşâasına başlandı" Ahmet Cevdet Paşa: 1309)

\section{Kemer-Edremid ve Osmanlı Donanması'nın İhtiyaçlarının Tedâriki 3.1 Malzeme ve Personel}

Kemer-Edremid'in Edremit körfezinde bulunması ve Kazdağlarının eteğinde yer alması gibi hususlar çevresiyle ve devlet merkeziyle kurduğu ilişkilerin niteliğinde belirleyici rol oynayan coğrafî özelikleridir. $\mathrm{Bu}$ özellikler nedeniyle ön plana çıktığı hususlardan birisi de Osmanlı donanmasının çeşitli ihtiyaçlarına yaptığı katkıdır.Kazâ, donanmaya ait birçok gereksinimin karşılanmasında ocaklık sistemi uyarınca düzenli bir şekilde çeşitli yükümlüklükleri yerine getirmektedir. Devletin bilhassa deniz kuvvetlerinin temel ihtiyaçlarına sarfetmek üzere kazâdan yaptığı talepleri genel olarak malzeme ve personel alanları olmak üzere ikiye ayırabiliriz. Malzeme talepleri kereste ile birlikte, güherçile ve katran gibi bölgenin üretim potansiyeli ile alakalı isteklerdir. Personel talepleri ise muharip deniz askerî sınıfı kalyoncular ile gabyar, marangoz vb. ikinci dereceden işleri gören hizmetli sınıfının tedarik edilmesini ihtivâ etmektedir.

Kemer-Edremid'den devlet tarafindan talep edilen malzemelerden ilk olarak harbin en temel ihtiyaçlarından olan barutun yapımında kullanılan güherçile'yi zikredebiliriz. Güherçile siyah barutu oluşturan üç madde içinde en önemlisi olup, külçe şeklinde ve madenî bir halde bulunmaktadır. odun kömürü ve kükürtle karşımı sonucunda barut üretilmektedir. Kullanımı daha ziyâde Haçlı Seferleri sonrasında başlayan güherçilenin 
İslam dünyasında yaygınlaşması Osmanlılar zamanına denk gelmektedir. Duyulan ihtiyaç nedeniyle Osmanlı coğrafyasının çeşitli yerlerinde güherçile karhâneleri kurulmuştu. Bunlardan en önemlisi İstanbul'da kurulan Baruthâney-i Amire idi. (Hülagü, 2001: s.74,78; Bostan, 2003: s.170)

Taşrada kurulan baruthâneler arasında en önemlilerinden birisi de Gelibolu Baruthânesi ydi. Tesis tarihi tam olarak bilinmemekle birlikte 1683 yılında faaliyete geçtiği kabul görmektedir. Bu baruthânenin güherçile tedârik ettiği yerler arasında Çirmen, Paşa, Gelibolu, Biga ve Midilli gibi sancaklarla birlikte Karesi sancağ 1 da vardı. 1668 senesinde zikredilen sancaklardan 1.323 .000 akçe tutarında 44.100 kıyye halîs güherçile alınmıştı. (Agoston, 2006: 191-192.) XVIII. yüzyıla gelindiğinde Karesi'den aynı maksatla güherçile tedariğine devam edilmekteydi. 19 Zilhicce 1143 (25 Haziran 1731) tarihinde Gelibolu'da hazırlanacak 2.000 kantar siyah barut için (barud-ı siyâh) kıyyesi 30'ar sağ akçeden Karesi kazâlarına 5.500 kıyye güherçile tevzî edilmiş, bu güherçileden Kemer-Edremid hissesine 939 kıyye isabet etmişti. (BRHŞS. 1093/21-a-1, 27-b-1; Karesi Sancağı'na tevzî edilen bir başka güherçile için: MAD.d.7488 vd.) Vukiyye veyâ ukîyye şeklinde de adlandırılan kıyye, aynı zamanda Osmanlı temel ölçü birimi olan okkanın diğer adıydı. 400 dirhem , 4 ratl-ı rumî bir kıyye ederdi. Modern ağırlık ölçülerine göre ise 1 kıyye 1282 grama tekâbül etmektedir. (Ünal: 2011 s.404, 528.) Bu rakamdan yola çıkarsak, Karesi Sancağı'na tevzî edilen güherçilenin günümüzde yuvarlak olarak $7.051 \mathrm{~kg}$.ye denk geldiğini tespit etmekteyiz. $7.051 \mathrm{~kg} .1 \mathrm{k} \mathrm{bu}$ güherçileden Kemer-Edremid hissesine düşen oran ise yine yuvarlak bir hesapla $1.203 \mathrm{~kg}$., veya 1 ton 203 kg.dir.

Güherçile'nin yanında bölgeden Tersâney-i Amire'ye gönderilen diğer benzer nitelikli malzemeler arasında zift ve katran yer almaktadır.(Karesî Vilâyetine Mahsus Salnâme-1305: s.75-76; Karesi Sancağında üretilen zift ve katran Tersâne'nin yanı sıra İstanbul, İzmir ve diğer sahillere ihraç edilmekteydi. Aynı Eser, 1305: s.75-76; sancak aynı zamanda çeşitli yeraltı zenginliklerinin bulunduğu bir bölge olarak madencilik yapılan bir yerdi. Bu konu hakkında Baykara-Taşkaya, 2011: s.1-16) Zift ve katranın yöreden alınmasına etken olan ana unsur çam ormanlarının varlığıdır. Zirâ çam ağaçlarından elde edilen zift ve katran gemilerin ahşap kısımları arasında dolgu malzemesi olarak kullanılmaktaydı. Zirâ suya karşı dayanıklılığı artıran bir maddeydi. Koyu siyah renkde yapışkan bir madde olan zift, soğuk iken sert, 1sıtıldığı zaman yarı sıvı halini almakta, kalafattan sonra gemilerin ek yerlerini tıkanmasında yararlanılmaktaydı. XVII. Asıra gelindiğinde bilhassa Midilli ve Avlonya'dan ocaklık olarak alınıor, bedeli ise Midilli gümrük gelirlerinden tahsis ediliyordu. Zift tedarik edilen yerler arasında Edremid, Tuzla, Ezine, Bayramiç ve Kazdağı havalisi de vardı. Örneğin 1701 tarihinde Kazdağ havalisinden bedeli Karesi ve Biga cizye gelirlerinden karşılanmak üzere 2.000 kantar zift alınmıştı. XVII. yüzyılın ikinci yarısında İstanbul'a gelen emtîanın genel bir listesini veren Mantran, reçineli kerestenin Limni-Edremit ve Kapıdağı'ndan, katranın Rodos, Menteşe ve Biga'dan, ziftin ise Edremid, Avlonya, Limni, İzmir, Kapıdağı ve Eğriboz'dan geldiğini bilgisini vermektedir. Uzunçarşılı ise katran ve ziftin birinci derecede Biga, Bayramiç, Tuzla Kazdağ 1 Ağrıboz ve Kastamonu, ikinci olarak Avlonya ve Midilli'den sağlandığını belirtmektedir. (Taş-İdigli, 2013: s.61; Bostan, 2003: s.130-131; Mantran, 1990: s.197-198; Uzunçarş111, 1988: s.451)

Zift ile birlikte donanmada ihtiyaç duyulan diğer benzer madde katrandır. Katran, zift gibi çam ağaçları ve maden kömürlerinden üretilen yapışkan bir sıvı olup, gemilerin omurgalarında ve su altında kalan kısımlarında kullanılmaktaydı. Tersâne-i Amîre için lüzumlu olan katran Kalây-1 Sultaniye'den (Çanakkale) ocaklık olarak alınmasının yanında, Midilli, Edremid, Tuzla, Ezine, Bayramiç ve Lapseki havalisinden de karşılanıyordu. Örneğin Biga ile Karesi Sancağından 1700 yılında 300 kantar katran karşılı̆̆ 300 guruş ödenerek, paranın zift örneğinde olduğu gibi Biga ve Karesi cizye-i gebrân gelirlerinden karşılanmasına karar verilmişti. XIX. yüzyılın ilk yarısında 15 Zilhicce 1253/10 Şubat 1838 tarihinde yine Biga ve diğer kazâlardan talep edilen 16.000 kantar katranın amelelerce çıkarılıp üretildiği (müretteb amelelerce hafr ve imâl) belirtilerek ertesi seneye mahsûb olmak üzere 3-4 ay içinde Tersâne-i Amîre'ye gönderilmesi isteniyordu. (Bostan, 2003: s.129-130; ESSS.1253/10-b-1)

Katran ve zift gemiler vasıtasıyla da Tersâne-i Amire'ye gönderilmekteydi. Bu nedenle alımlarda masraflara eklenen diğer kalem ise navlundur. Örneğin Kalâ-i Sultaniye'den 1661-62 tarihinde alınan zift için 1361 akçe tutarında navlun ödenmişti. 3 Şabân 1172/1 Nisân 1759 tarihinde ise Midilli'de inşâ edilecek bir kalyon 
için Edremit ve Kemer-Edremid'den alınan 1.000 kantar katrana, kantar başına tulum-bahâ ve navl-ı sefine ile 1 guruşluk fiyat tespit edilmişti. (Bostan, 2003: s.128-129; EŞS. 1253/10-b-1, 1249/92-a-4; Edremid Şeriye Sicilleri'nde bilhassa 1243 nolu defterden itibaren çok sayıda zift ve katran tevzîi mevcuttur. Ayrıca, zift ve katranın ocaklık olarak tedarik edildiği bölgenin kereste ile aynı olduğu görülmektedir. Bostan, 2003: s132, BRHŞS.1094-21-b-1.)

Osmanlı ölçü birimlerinden birisi olan ve 44 okka yani 56.452 kg.ye tekâbül eden kantar, aynı zamanda ağır maddelerin ölçümünün yapıldığı tartı aletine verilen isimdi. Kıyye örneğinde gördügüumüz gibi kantarın birimi de yörelere ve zaman dilimlerine göre farklı rakamlar ihtivâ etmekteydi. Örneğin XIX. yüzyılda 1 kantar 180 okka, yani $230.922 \mathrm{~kg}$. olarak değerlendiriliyordu. (Ünal, 2011: s.372) Güherçile hususunda olduğu gibi burada da yuvarlak bir hesapla bir kantarı $231 \mathrm{~kg}$. kabul edersek, iki kazâdan alınan 1.000 kantar katranın $231.000 \mathrm{~kg}$. ya da 231 tona denk geldiğini tespit edebiliriz.

Uzun deniz seferlerinde gemilerdeki mürettebatın yiyeceklerinin karşılanması maksadıyla çeşitli gıda maddeleri hazırlanırdı. Bunların başında bir nevi kurutulmuş ekmek olan peksimet gelmektedir. Donanma denize açılmadan önce her sene gemi varlığına göre peksimet hazırlamak devletin vazifeleri arasındaydı. Denizde olduğu kadar, uzun kara seferlerinde de peksimete ihtiyaç duyuluyordu. Peksimet İstanbul ya da seferin yapıldığı yere yakın bölgeden tedarik edilirdi. Bir kantar peksimet için 2.5 keyl (kile) buğdaya ihtiyaç vard1, kantar başına ise 20 akçe ücret ödeniyordu. 1692-93 senesinde talebin artması ile pişirme ücretinin yükseltilmesi üzerine alım fiyatı 40 akçeye çıkmıştı. İstanbul'dan sonra peksimet pişirilen ikinci merkez baruthâne örneğindeki gibi yine Gelibolu'ydu. Peksimet türleri ise buğdayın kalitesine göre değişmekteydi. Kapudan Paşa baştardasına peksimet-i has, (peksimet-i hass-ı beyâz) gemilerde görevli kapıkuluna peksimet-i beyaz ve forsalara peksimet-i harcî adlı peksimet çeşitleri verilmekteydi. Seferlere yakın yerlerde hazırlanan peksimetler gemilerle nakl ediliyordu. Ayrıca bu peksimetin taşıma ücreti, nakliyesinde kullanılan çuval, çivi ve hasr gibi malzemeler ile taşıma masrafı olan hammalîye ücreti de maliyete dahil edilmekteydi.(Bostan, 2013: s.244-245-246, 249)

Kemer-Edremid kazâsının karşıladığı hizmetlerden birisi de peksimetin pişirilmesi için lazım olan dakîkin (un) hazırlanmasıydı. Gurrey-î Şaban 1216/7 Aralık 1801 senesinde yine Hadımzâde Osman Bey marifetiyle Çanakkale'ye sevk edilmesi istenen 10.000 kantar peksimet için, Karesi'ye 16.667 kile dakîk tevzî edilmişti. Ancak Kemer-Edremid ve Edremit ahalileri Çanakkale'nin kendilerine uzaklı̆̆ının yanı sıra, çekirge istilâsı nedeniyle zahire yokluğunu öne sürerek (...kazahây-ı merkûme Çanak-kal'aya baîd ve mesâfe olmak takarrübüyle dakîk nakli adîm'ül-imkân olduğundan başka, iki seneden beru cerad istilâsı sebebiyle mahsûlatları telef olub, ekvât-ı yevmîyelerini diyâr-ı aherden temin eylediklerinden) talep edilen dakîkikin kile başına 4.5 guruş bedelle alınmasını talep etmişlerdi. Başkent bu isteği kabul etmiş, 7 Şevvâl 1216 /10 Şubat 1802 tarihinde 1214 (1799-1800) ve 1215 (1801-1802) senelerine mahsuben Edremit ve KemerEdremid'e isabet eden 505'er kileden toplam 2.020 kilenin bedeli olarak her iki kazâya 9.090 guruş tarh edilmişti. Bu meblağdan Kemer-Edremid hissesine denk gelen tutar ise 4.545 guruştu. (BRHŞS.1094/62-a3,63-b-5)

Kemer-Edremid bahsedilen malzeme ve iaşe maddelerinin yanı sıra donanmaya nakliye ve iaşe konularında da hizmet vermekteydi. Genellikle kara ordusunu için talep edilen bu hizmet ve yükümlülükler kapsamında 17 Şaban 1225/17 Eylül 1810 tarihinde Rus Seferi münâsebetiyle Karesi Sancağı'na 350 adet mekkâri şütürân tevzî edilerek bedellerinin alınmasına karar verilmiş, Kemer-Edremid ve Edremit'e ise 135'er guruşdan 7'şer adet deve isabet etmişti. Kazâ aynı zamanda başkentteki kapıkulu ordusunun et tayinatına da katk1 yapmaktaydı (Ayrıca 1237/1821-22 senesinde eski Sadrazâm Rauf Paşa'nın emri altında toplanacak ordunun nakliye hizmetleri için Kemer-Edremid'den 5 adet bargîr alınmıştı.Nakliye vasıtalarının alımının bazı zamanlarda Donanma için de yapıldığı görülmektedir.11 C.Ahîr 1215/ 30 Ekim 1800 tarihinde donanmada istihdâm edilmek üzere Karesi Sancağı'na tarh edilen 300 mekkâri şütürândan (develer) KemerEdremid'e 4.200 guruş değerinde 28 deve tevzî edilmişti. (BRHŞS. 1094/58-a-2,102-b-2,106-a-2,107-a, 1095-A/ 22-2, 49-b-2.)

Çeşitli malzeme ve iaşe maddeleriyle birlikte, Kemer-Edremid'in Osmanlı ordusuna yaptığ 1 diğer mühim katkı ise muvazzaf asker techîzidir. İmparatorluğun sık s1k uğraşmak zorunda kaldığı isyanlar ve savaşlar 
neticesinde ülkenin diğer yerlerinden olduğu gibi Kemer-Edremid'den de çeşitli zamanlarda asker celbediliyordu. Örneğin 23 Muharrem 1205/2 Ekim 1790 tarihinde Kemer-Edremid Voyvodas1 Halil Ağa'dan 300 piyade asker hazırlayarak Edirne'de muhafaza hizmetinde bulunması istenilmiştir. 17 Safer 1225 / 24 Mart 1810 tarihinde ise Rus savaşı nedeniyle Kemer-Edremid kazâsından talep edilen 300 askerin bedeliyesi olan 500 guruş kazânın salyâne defterine eklenmişti. 23 Receb 1236 /26 Nisân 1821'de Rumlar tarafindan girişilen ilk isyân girişiminin meydana geldiği Eflâğa müdahalede bulunulmak üzere Edremit ve Kemer-Edremid'den 50 süvari ve 250 piyade asker talebinde bulunulmuştu. Gurrey-î Şabân 1238 / 13 Nisân 1823 tarihinde bu kez İran savaşı nedeniyle Karesi'ye tarh edilen 1000 süvâriden Kemer-Edremid'e her biri 36 guruş bedele sahip toplam 105 süvari askeri isabet etmişti. (BOA.C.AS..667-28028, 403-16655; BRHSSS.1094/103-a-2, 1095-A/15-a-3; Savaşlar neticesinde ortaya çıkan isteklerin yanı sıra, gerçekleştirilen modernleşme hareketleriyle birlikte tesis edilen Nizâm-1 Cedîd ve Asakîr-i Mansûre gibi yeni ordular için de Kemer-Edremid asker katkısı yapmıştır. (BRHŞS.1094/76-a-2,b-2, 79-a-2,1095-A/36-a-1 vd.) Kazâdan sıkça alınan bu askerlerin belirlenen adetlerde, belirlenen zaman kapsamında, beklenilen noktalara gönderilmesinin meşakkâtli ve zor olduğuna şüphe yoktur.

Kemer-Edremid ve diğer Karesi kazâları asırlara yayılan denizcilik geleneğine sahip bir bölgede olmaları sebebiyle, kazâdan Osmanlı donanması için donanma askeri talebi yapılıyordu. Bu bağlamda, şeriye sicillerinde çeşitli tarihlerde merkeze gönderilen kalyoncu neferleri hakkında çok sayıda belge örneği bulunmaktadır.19 R.Evvel 1213/31 Ağustos 1798 tarihinde Napolyon'un Misır'a yaptığı ani çıarma nedeniyle Hüdavendigâr, Karesi, Saruhan, Sığla Sancaklarıyla, İzmir ve Gelibolu taraflarından kalyoncu neferleri tertip edilmişti. Bu neferlerden Karesi Sancağı'na 165, Kemer-Edremid'e ise 13 nefer düşmüştür. Her birinin 23'er guruşdan toplam 299 guruş tutan mîrîleri (maaşları) sicile kaydolunmuştu. 13 Zilhicce 1222/ 11 Şubat 1808 'de ise taşradan Donanmay-1 Hümâyun kalyonları için alınacak bayrak neferâtından Kemer-Edremid'e biri ağa, biri alemdâr olmak üzere 75 nefer isabet etmiş, bu askerlerden ağaya 50, alemdara 28.5 ve geri kalan 73 nefere kişi başına 73.5 'er guruşdan iki kıst mevacibleri olmak üzere mübaşir vâsitasıyla 1.757.5 guruş gönderilmişti. (BRHŞS. 1094/51-a-1,a-2, 88-a-1 vd. Kalyoncu neferi gönderecek olan her kazâ bir ağa ve bir alemdâr ile birlikte bu neferleri göndermekte idi; Gencer, 2001: s.62)

Kalyoncu neferlerini takiben donanmaya gönderilen diğer personel ise yukarıda sözünü ettiğimiz gabyarlardır. 23 C.Ahir 1237 /17 Mart 1822 tarihinde kazâdan 500'er guruş yevmîye ile 4 adet gabyâr Tersâne-i Amîre hizmetlerinde görev yapmak üzere celb edilmişti. Gabyarları müteakiben donanmaya gönderilen diğer bir hizmetli sınıfı ise tamir işlerinde kullanılacak kalifiye elemanlardı. Ormanların yoğun olduğu yörede buna paralel olarak ahşap işleriyle uğraşan esnaf bulunuyordu. Sicillerde bu esnaflardan bazılarının terekelerine rastlamaktayız. Bunlardan birisi 27 C.Evvel 1245/M 24 Kasım 1829 tarihinde Edremid'de bir vakıf handa doğramacılık sanatıyla meşgul iken vefat eden Biga'lı Kapudan Ömer Beşe'dir. Kapudan Ömer Beşe'nin 217 guruşluk servetini oluşturan muhallefâtı arasında dülger alâtı, keten bezi, keten çıkrı̆̆ı, hırdavat, nacak ve demir hırdavatı gibi meslekî aletler mevcuttu. Bu aletlerin diğer tamîr faaliyetleri gibi gemi tamiri esnasında da kullanıldığı açıktır. Ayrıca Ömer Beşe'nin kapudan ünvânı denizcilikle olan bağlantısını göstermesi açısından dikkat çekicidir. Aynı iş koluyla iştigâl eden meslek sahiplerinden KemerEdremid'de faaliyet gösterenler bazı zamanlarda donanma hizmeti göreve çağırılmaktaydılar. Tarihi tam tespit edilemeyen bir belgeye göre Kemer-Edremid'den alınan 71 kişilik personelden birinin ağa, 40'ının gemide görev yapacak mürettebât ve 30'unun da gemi tamirinde istihdâm edilecek kişiler olmasını kazânın deniz kuvvetlerine başka bir katkısı olarak değerlendirebiliriz. Kemer-Edremid'li zanâat sahiplerinden başka alanlarda da faydalanılıyordu. 25 R.Evvel 1231/ 25 Mart 1816 tarihinde, Bozcaada kalesinin tamir edilmesi maksadıyla Midilli'den amele alınmış, geri kalan ziftçi, neccâr, duvarcı, dülger ve kireççi gibi zanaatkârların ise Balıkesir kazalarıyla Biga ve Manisa'dan karşılanması kararlaştırılmıştı. Bu bağlamda, Kemer-Edremid köylerinden üç adet marangoz hizmetleri karşıllğ̣ 40 'ar guruş yevmiye ücret ile Bozcaada'ya gönderilmişti. (BRHŞS.1095-1/20-5; ESSS.1250/65-a-3; BRHŞS.1095-1 4-4, 4-5,11-1)

Kalyoncu neferi tertibi konusunda vurgulanması gereken diğer bir nokta, neferlerin adet olduğu üzere aynen alınmasının terkedilip, bunun yerine bedellerinin verilmesiydi. Bu bedeller ruz-1 kasım ve rûz-1 hazerde (bahar) tahsil edilmek üzere nefer başına 500'er guruş olacaktı. 26 R.Ahîr 1246/14 Ekim 1830 tarihinde Kemer-Edremid'den 77 adet kalyoncu neferinin bedeliyesi olarak 500'er guruşdan toplam 38.500 guruş, 
Tersâne-i Amire Hazînesi'ne tahsis edilmişti. (BOA.C..BH..130-6288; Donanma masraflarına katkı yapmak amacıyla hayata geçirilen kalyoncu bedeli tahsili uygulaması hakkında Yiğit: 2009, s.129; Gencer: 2001 s.61,63)

Osmanlı Devleti Macaristan'ı işgal ettikten sonra diğer donanmalarla birlikte Tuna nehrinde de bir donanma ihdas edilmiş ve bu donanmaya Tuna kaptanlığı adı verilmişti. İki mıntıkaya ayrılan Tuna kaptanlığında her mıntıka kaptanının emri altında onar firkate ve bahriye azapları mevcuttu. XVII. yüzyıl sonlarında Silistre'den Belgrad'a kadar olan Tuna sahillerinde on iki adet ocaklık şayka ile kaptan bulunuyordu. Macaristan'ın elden çıkması üzerine kaptanlık mıntıkası bire indirilmiştir. Tuna nehrinde şalope, aktarma ve kırlangıç gibi türler muhafaza hizmetinde kullanılmaktaydı. (Uzunçarşıll, 1988: 403-404) Tuna kaptanlığında hizmet veren bu gemilere ait masrafların karşılanmasında Kemer-Edremid'in ocaklık uygulaması kapsamında yine katk1 sağladığı görülmektedir. 21 Zilhicce 1233/22 Ekim 1818 tarihinde Tuna sahilinde inşâ edilecek şalope ve sandallarda vazife yapacak neferlerin maaşları için gelecek seneye (1819) mahsuben Kemer-Edremid'in bedel-i avârız ve nüzûl mallarından 40 guruş ayrılmıştı. 25 Zilhicce 1237/12 Eylül 1822 tarihinde ise yine 1238/1823 senesine mahsuben bedel-i avarız ve nüzûl mallarından 40 guruşun tahsili emredilmişti. (BRHŞS.1095-A/9-b-2,16-b2)

\section{Tarihî Dönemler Açısından Donanma Gemileri}

Osmanlı denizcilik tarihinde gemiciliğin gelişimi genel olarak üç kısma ayrılmaktadır. Bunlardan ilki imparatorluğun kuruluşundan XVII. yüzyılın ikinci yarısına kadar devam eden kürekli gemiler (kadırga veya çektiri) dönemi, ikincisi XIX. yüzyılın ortalarına kadar devam eden yelkenli gemiler (kalyon) dönemi, üçüncüsü de imparatorluğun yıkılışına kadar devam eden buharlı gemiler dönemidir. (Bostan, 2004: s.67) Kuruluş döneminden XVII. yüzyılın sonlarına kadar Osmanlı donanmasındaki harp gemilerinde en çok kullanılan ve vurucu deniz gücünü teşkil eden gemi çeşidi kadırga idi. Kadırgalar gayet uzun ve ensiz, kısmen su seviyesinde denilebilecek kadar alçak bir yapıya sahip ise de, hareketleri pek seri idi. Kanun olarak donanma için her sene 40 kadırga yapılması kararlaştırılmıştı. Kalyon devrinin başlamasıyla birlikte, III. Ahmed devrinden itibaren sayıları azaltılan kadırgaların üretimi I. Abdülhamid zamanına gelindiğinde tamamen terkedilmiş, yalnızca kadırga tipinde Kaptan Paşa baştardesi üretilmeye başlanmıştı. (Bostan, 2003: s.85; Uzunçarş111, 1988: s.463)

Kadırgalardan sonra donanmada yer alan kalyonların kullanılmasında XVII. yüzyılın ilk yarısında yapılan Girit seferi etkili olmuştur.1055-1080 /1645-1669 yılları arasında yaklaşı 25 yıl süren bu savaş Osmanlı denizciliği açısından bir dönüm noktası teşkil etmişti. Muharebe esnasında kalyona geçme teşebbüsünde bulunulduysa da temel donanma gücü yine kadırgalardan ibaret olmuştu. Savaş esnâsında daha ziyâde korsanlık ve ticaret yapmak amacıyla Akdeniz'e gelen Fransız ve Hollanda gemilerinin üstünlüğü açıkça ortaya çıkmıştı. Venedik bu devletlerin gemilerini kiralayarak Osmanlı donanmasını engellemeye, hatta Çanakkale Boğazı'ndan malzeme ve mühimmât sevkini engellemeye çalışmış, güç dengesini Osmanlı aleyhine bozmuştu. $\mathrm{Bu}$ nedenle kalyonların denizlerdeki etkisini gören devlet adamları bazı müzakere ve istişârelerden sonra kalyon inşasına karar vermişlerdir. XVII. yüzyılın ikinci yarısına gelindiğinde iki aşamalı bir süreci takiben Osmanlı denizciliği tamamen kalyona geçmişti. İlk aşama, 1060-1072/1650-1662 yılları arasındaki deneme dönemi olup, sonrasında yeniden kadırgaya dönülmüştür.1093 /M.1682 yılında ise Osmanlı donanmasına kalıcı ve kesin olarak kalyon dönemi başlamıştır. (Bostan, 2004, s.69-70-71; Kalyon'un Osmanlı donanmasında önem kazânması için ayrıca bkz. Güleryüz, 2005; Guilmartin, 2010; Aydın, 2011. vd.)

XIX. yüzyılın ikinci yarısından sonra buharlı gemilerin kullanımına geçilmesine kadar Osmanlı gemiciliğinin ana unsurları kalyon-kadırga gemileri veya diğer adıyla kürekliler-yelkenlilerdi. Kürekli gemiler sınıfına girenlere çektirme, çektirir, çektiri gibi isimler verilmekte, yalnız yelkenle hareket edenlere ise yelkenli veya kalyon sınıfi gemiler denilmekteydi. Kürekli gemiler sınıfında büyük donanma gemileri arasında firkate, kalyate (kalyata), kadırga, baştarda, mavna, ince donanma gemileri arasinda ise karamürsel, şayka, işkampoye, üstüaçık, çekevele, kancabaş, at gemileri, taş gemileri, top gemileri, at kayığl, ateş kayı ̆̆ gibi gemi çeşitleri bulunuyordu. Yelkenli gemilerde ise kalyon, burtun, barça, eğribar gibi çeşitli isimlere sahip gemiler ve deniz araçları mevcuttu. (Bostan, 2003: s.83-96; Uzunçarş1l1, 1988: s.455-479) 


\subsection{Osmanlı Devletinde Gemi İnşâ Yerleri ve Kemer-Edremid Tezgâhı}

Kuruluşu ve tarih sahnesine çıkışıyla birlikte hızla genişlemeye başlayan Osmanlı beyliği bir süre sonra sınırlarını Ege ve Marmara'ya ulaştırarak deniz kuvvetlerini teşkîl etmişti. İlerleyen asırlarda büyüyerek imparatorluk karakteri kazanan beylik, aynı büyümeyi denizlere de yansıtmış, XV-XVI. yüzyıllarda dünyanın en güçlü donanmasına sahip olmuştu. Fakat, zamanla siyasî, askerî ve ekonomik alanlarda ortaya çıkan birçok sorun nedeniyle kudretini yitirmeye başlayan devletin kurumları da bu gelişmelerden benzer şekilde etkilenmişti. Eski dönemlerde elde edilen başarıların geri kazanılması maksadıyla, modernleşme ve ıslah çalışmalarına girişilerek problemlere köklü çözümler aranmaya başlanmıştı. Bu çalışmaların yapıldığ 1 kurumlardan birisi de donanmaydı.

XVI. yüzyılın ikinci yarısında yaşanan İnebahtı yenilgisinden sonra, ağır kayıp veren Osmanlı donanması yeniden ve daha güçlü bir şekilde inşâ edilmiş, çeşitli tersâne ve tezgâhlarda beş ay gibi kısa bir sürede çok sayıda gemi yapılmıştı. Denizlerde Avrupa devletleriyle girdiği mücadelelerdeki üstün konumunu bir süre sonra yitiren Osmanlı donanması, XVII. yüzyılın başlarına gelindiğinde gerilemeye yüz tutmuştu. Barbaros Hayrettin Paşa ve Turgut Reis gibi tecrübeli denizcilerin yetişmemesinin yanı sıra, gemicilik alanında yaşayan yenileşmenin dikkate alınmaması gibi sebepler bu gerilemenin en temel nedenleri arasındaydı. Yukarıda kısaca ifade edildiği gibi, Lepanto savaşını müteâkiben yelkenli gemi devri kapanmış, Akdeniz'in eskiden beri en güzîde savaş gemisi olan kadırganın modası geçmeye başlamıştı. Başka bir deyişle kürek devri yerini kalyon devrine bırakmıştı. (Uzunçarş111, 1988: s.444-445; Gencer, 2001: s.22)

XVIII. yüzyıl sözkonusu olduğunda, Osmanlı donanmasını etkileyen diğer bir önemli olay ise yine bir mağlubiyet niteliğindeki Çeşme vakâsıdır. 1768 tarihinde başlayan savaşta Rus Baltık filosu Akdeniz'e gelerek 1770 senesinin Mart ayında Koron'u muhasaraya başlamıştı. Rus donanmasının amacı Mora yarımadasındaki Rumları ayaklandırarak Osmanlı devletini sıkıştırmaktı. Ancak Navarin'deki Rum isyânını bastıran Osmanlı ordusu Rus donanması ile çatışmaya başlamış. 6 Mayıs 1770 tarihinde Koyun Adaları önündeki son çatışmada her iki tarafta çıkan yangınlar nedeniyle donanmalar savaş alanından çekilmişlerdi. Bu noktada Osmanlı donanması stratejik bir hata yaparak manevra kabîliyetinde bulunamayacağı Çeşme limanına demirlemiş, fırsattan yararlanan Ruslar İngilizlerin yardımıyla Osmanlı donanmasını yakmışlardı. Tüm donanmadan sadece Kaptan-1 Deryâ Hüsameddin Paşa'nın baştardesi kurtulmuştu. (Özdemir, 2005: s.116-117)

1770 yılından sonra yaşanan bu hadiseden sonra Osmanlı donanmasının yeniden inşâ edilmesine başlandı. Yapılan çalışmalarla 1790'a gelindiğinde donanma irili ufaklı 90 gemiden oluşmaktaydı. Bu gemiler 18 kalyon, 24 fırkateyn, 6 kırlangıç, 10 çektiri-şehtiye, 8 şalope, birkaç brik, 20 kadar da bülbüllüce, suluca, çamlıca, kerpe ve Rum tirhandilleri tipindeki gemilerdi. Uzun süreden beri ortaya konulan düzensiz hareketler III.Selim'in tahta çıkmasıyla birlikte, bilhassa 1787-92 harplerini takîben giriştiği reform hareketleri ile önlenebilmiş, 1804 senesinde çıkarılan bir kanunâme ile idarî işlerin esasa bağlanması sonucunda, bahriye meselesi ciddi biçimde ele alınmıştı. (Gencer, 2001: 27-28-29)

XIX. yüzyılın ilerleyen yıllarında III.Selim zamanında başlayan, ancak devam ettirilemeyen sslâhatlara tekrar hız verilmişti. Bu ıslahatlarla birlikte ülkenin bütün kıyılarında, özellikle Anadolu sahilleri ve bazı Ege adalarında kalyon, fırkate, brik, korvet vb. gemiler inşâ ediliyordu. 1811 yılında Osmanlı donanmasının mevcudu kalyon, firkateyn ve korvet olarak büyük küçük 42 parçadan ibaretti.1820 yılında ise henüz bitmeyenler hariç, firkateyn, korvet, brik, uskuna, ve şalope gibi hafif savaş gemilerinden başka 20 kadar kapaklı kalyon ve üç-anbarlı (kalyon) türünden muharebe birlikleri vücuda getirilmişti. (Gencer, 2001: s.106)

Osmanlı donanmasını oluşturan gemiler başta Gelibolu ve İstanbul tersâneleri olmak üzere Karadeniz, Marmara ve Akdeniz sahillerindeki birçok iskele ve mevkîlerde inşâ edilmekteydiler. Ortaya çıkan ihtiyaç nedeniyle yapılacak gemilerin miktar ve çeşitleri hükümet tarafından belirlenerek inşâ edileceği mahallin kadılarına bildirilir, tamamlanması gereken süre tayîn olunurdu. Gereken malzeme inşâ mahallinden temîn edilir veya merkezden gönderilirdi. (Uzunçarş111, 1988: s.445)

Başta başkentteki Tersâne-i Amîre bünyesinde olmak üzere, imparatorluğun farklı yerlerinde çeşitli gemi inşâ tezgâhları bulunuyordu. İlk olarak Kasımpaşa sahilinde yapılan Tersâne-i Amîre sonraları genişletilmiş 
ve tezgâh sayısı beşe çıkarılmıştı. XVIII. yüzyılın sonlarına doğru ise Hasköy ve Ayvansaray semtlerinde Tersane-i Amîre'nin devamı olarak ikişerden toplam dört tezgâh daha yapılmıştı. Uzunçarşılı XVI. yüzyıl sonlarındaki mühimme defterlerine dayanarak imparatorluktaki tezgâhların bulundukları diğer yerler arasında Samsun, Sinop, Amasya, Kefken, Midye, Ahyolu, Süzebolu, Varna, Marmara bölgesinde Yalova, İzmit, Gemlik ve Biga Kemeri, Akdeniz'de Rodos ve Antalya gibi yerlerden bahsetmektedir. Bu tezgâhların yanı sıra Gelibolu'da mevcut olan tersânede Kadırga ve diğer gemiler inşâ edilmekte olduğunu, Marmara bölgesindeki Gemlik tersânesinde büyük harp gemisi inşâ edilidiği bilgisini vermektedir. Burada 1792 tarihinde 55 ziralık (bir zira-i mimâri 75.8 santimetredir.) 1799'da 51 ziralık, 1805 tarihinde ise 59 ziralık firkateynler yapılmıştır. (Uzunçarşı11, 1988: s.505; Osmanlı Donanması'ına ait gemilerin üretildiği tersâne ve tezgâhların XVI. yüzyıldaki durumu hakkında Bostan, 1988: s.125-129)

Uzunçarşılı devâmla, tersanelere göre daha küçük boyutlarda olan gemi inşâ tezgâhlarından bazılarını zikretmektedir. Bunlar Marmara'da küçük ebatlardaki bazı teknelerin yapıldığı Karabiga, kerestesinin Kazdağlarından tedârik edildiği Çanakkale, orta derecede gemilerin yapıldığı Biga Kemeri (Kemer-Biga), Molve (Midilli-Molova) ve Bodrum tezgâhlarıdır. Gemi yapılan yerler arasında Rodos tersânesi, Karadeniz sahilinde Misivri, Varna'nın kuzeyinde Çingane İskelesi, Karadeniz Ereğlisi, Bartın, Amasra, Silistre ve Kalas tezgâhlarıyla Sinop tersânesi gibi merkezler de bulunmaktadır. Uzunçarşı1ı'nın ismini verdiği tezgâhlardan birisi de Ege sahilinde bulunan Kemer Edremit (Burhaniye) tezgâhıdır. (Uzunçarşı1lı, 1988: s.505-506; Akdeniz ve Adalarda gemi inşâ edilen mevkîiler için: TSMA.d.2719.)

XVIII. asrın başlarına gelindiğinde Karadeniz sahillerinde 44, Tuna nehri üzerinde 6, Marmara ve Akdeniz sahillerinde 15 olmak üzere ülke genelinde toplam 65 gemi tezgâhı mevcuttu. Bunlar arasında Karadeniz sahilinde Şile, Kerpe, Akçaşehir, Alaplı, Ereğli, Bartın, Amasra, Kitros, İnebolu, Alavra, Gerze, Çayağzı, Küplüağzı, Ünye, Giresun,Tirebolu, Görele, Trabzon, Rize, Gönye, Azak, Taman, Kerş, Kefe, Balıkağa, Gözleve, Özi, Akkirman, Kili, Karaharman, Köstence, Mankalya, Kavarna, Balçık, Varna, Misivri, Ahyolu, Burgos, Kamçısuyu, Süzebolu, Vasilikoz, Ahtabolu, İneada, Vize tezgâhları, Tuna nehri üzerinde İsmail Geçidi, Vidin, Semendire, Niğbolu, Mohaç ve Budin tezgâhları, Marmara bölgesinde Sakarya nehri üzerinde inşâ faaliyetleri yapılmakla birlikte Sapanca, Silivri, Kemer, (Biga-Kemer) Biga ve Samanlı tezgâhları, Ege ve Akdeniz sahillerinde Sakız, İstanköy, Rodos, İnebaht1, Preveze, Avlonya, Nova, Antalya ve Kuşadası tezgâhları gibi üretim yerleri bulunuyordu. (Bostan,2003: s.28; Osmanl1 imparatorluğu bünyesindeki tersâneler ve gemi inşâ edilen tezgâhlar hakkında detaylı malûmat için Bostan, 2003: s.3-7, 14-24 arası, ve s.29-Harita)

Osmanlı imparatorluğu sınırlarında mevcut gemi inşâ noktaları hakkında bilgi veren diğer bir kaynak ise Gencer'dir. Uzunçarş1lı ve Bostan ile benzer inşâ yerleri isimlerini sayan Gencer, İstanbul'daki Tersâne-i Amîre ile birlikte Bodrum, Gemlik, Kâla-i Sultâniye (Çanakkale), Midilli, Sinop, Rodos, Karadeniz Ereğlisi, Limni, Kıbrıs, Kemer, Kalas, Silistre ve Sohum tersânelerinden bahsetmektedir. (Gencer, 2001, s.53; Gencer'in bu ifadeleriyle yukarıda tezgâhlardan bahseden diğer kaynaklardaki veriler birlikte değerlendirildiğinde tersâne ile tezgâh terimlerinin bazen aynı anlama gelecek şekilde kullanıldığ 1 düşünülmektedir.)

Gencer, yukarıda saydığı yerler ile birlikte Yıldız Sarayı arşivinden tespit ettiği bir listeye dayanarak, Tersâne-i Amîre sahâsı, Gemlik sahâsı, Akdeniz Boğazındaki Sultaniye sahâsı, Limni Adası, Midilli Adası, Bodrum Sahas1, Karadeniz sahîlinde Ereğli sahâs1, Sohum sahâsı, Sinop sahâs1, Kalas ve Sisam gibi tezgâhlardan bahsetmekte, bunların dışında Ege sahillerinde Kemer (Biga- Kemer), Karadeniz sahilinde Misivri, Varna kuzeyinde Çingâne İskelesi ile birlikte, Bartın, Amasra ve Silistre tezgâhlarının varlığını belirtmektedir. Bütün bu tezgâhların hepsi Tersâne-i Amîre'ye bağlı olup kapasiteleri nisbetinde donanmaya gemi inşâ etmekteydiler. (Gencer, 2001, s.53,56 ve s.106)

Gencer, Uzunçarşılı'dan naklederek adı geçen bu tezgâhlarla birlikte Ege sahillerinde firkateyn inşâsına müsait bir kapasiyeye sahip Kemer tezgâhı ile Edremit'e bağlı Burhaniye tezgâhının bulunduğundan bahsetmektedir. (Gencer, 2001: s.56) Gencer'in verdiği bu bilgi hususunda şunu söylemek gerekmektedir ki, Kemer adıyla bahsettiği tezgâh Kemer-Biga tezgâhıdır ve Ege sahillerinde olmayıp, Marmara denizinin güneyinde Erdek yarımadasının bitişiğinde Karabiga'da yer almaktadır. Ayrıca Edremit'in Burhaniye'den 
ayrı olarak bünyesinde gemi inşâ tezgâh bulunmaktadır ve belgelerde bu mahalden "Edremid tezgâhı" adıyla bahsedilmektedir. (Kemer ve Kemer-Edremid tezgâhlarının konumları için bkz. Tekin-Baş, 2003: Cezâyir-i Bahr-i Sefîd-Harita 31; BOA.C..BH..136-6584; Gencer muhtemelen Uzunçarșılı'nın Merkez ve Bahriye Teşkilâtı adlı eserinde gemi inşâ edildiğini belirttiği Edremit kemeri (Burhaniye) mahalli ifadesini farklı değerlendirmiştir. Karşılaştırma için bkz. Gencer, 2001, s.56; Uzunçarş111, 1988: s.504-506.)

Osmanlı denizciliğine yaptığı katkı açısından değerlendirildiğinde, Kemer-Edremid'i önemli kılan diğer bir özellik zikredilen tezgâha ev sahipliği yapmasıdır. Vakanüvîs Halil Nuri Bey'in tarihindeki 1794-95 senelerine ait kayıtlarda donanmanın eksiklerinin giderilmesi kapsamında Tersâne-i Amîre'de yapılan kalyonlardan başka Akdeniz ve Karadeniz'in uygun yerlerinde ara ara gemi inşâ edildiği, bu yerlerden birisinin de Edremid kemeri (Kemer-Edremid/ Burhaniye) adlı mahal olduğu, ancak buranın büyük kalyon yapımına elverişli bulunmadığı ve sadece fırkateyn inşâ edilebildiği ifadeleri yer almaktadır. Halil Nuri Bey devamla Edremid kemeri yerine kalyon yapımına hem fizikî hem de coğrafî açıdan müsait olduğu tespit edilen Sultanîye, yani Çanakkale'nin tercih edildiği bilgisini vermektedir. Uzunçarşı11, Halil Nuri Bey'in ifadelerini tasdîk ederek, burada orta büyüklükte gemiler yapıldığını, 1723 tarihinde Didey-i Nusret firkateyninin, 1772 tarihinde ise iki adet geminin inşâ edildiğini belirtmektedir. 1770 Çeşme facîasından sonra Cezâyirli Gazî Hasan Paşa'nın yeniden yapılanma gayretleri kapsamında Kemer-Edremid (Yakıtal'ın ifâdesiyle Edremid-Kemer) tezgâhında dört yeni firkâteyn inşâ edildiği kaynaklarda yer almaktadır. Fırkateyn gibi büyük çapta gemilerle birlikte XVIII. yüzyılın sonlarında Kemer-Edremid tezgâhında daha küçük çapta deniz taşıtlarından birisi olan teknenin inşâ edildiğini de görmekteyiz.15 Muharrem 1203 /16 Ekim 1788'de Kemer-Edremid voyvodası El-Hac Halil Ağa marifetiyle bir kıt'ası 22, bir kıt'ası 19 zira uzunluğunda 2.000'er guruş tutarında iki teknenin inşâ edilerek Tersâney-i Amîre'ye gönderilmesi emredilmişti. XIX. yüzyılın ilk yarısında da Kemer-Edremid tezgâhında gemi yapımına rastlanmaktadır. 29 Zilhicce 1255 /4 Mart 1840'ta Kemer-Edremid voyvodası Mehmed Emin Ağa nezâretiyle bir kalyon inşâ edildiği görülmektedir. Bu konu hakkındaki belgede inşâ edilen mahal açıkça belirtilmemiştir. Ancak, kalyonun tob güzeştesi ve taşra tahtaları'nın yapımına başlandığı, geminin tamamlanması için gereken lata ve koğuş çam kerestelerinin dağdan kesilerek hazırlandığı ifade edilmektedir. İleri bölümlerde görüleceği gibi Kemer-Edremid'in donanmaya gönderdiği kereste çeşitleri arasında başta bu türler geldiğinden, inşâ mahallinin Kemer-Edremid tezgâhı olduğu sonucuna varılmıştır. Bunlarla beraber Halil Nuri Bey ve diğer kaynakların ifadelerinden yola çıkılarak eğer bir inşâ sözkonusuysa, yapılan kalyonun muhtemelen orta derecede büyüklüğe sahip olduğu düşünülmektedir. (Uzunçarş111, 1988: s.504-506; Yakıtal, 1985: s.29; BOA.C..BH..25-1200, 145-6957)

Makale kapsamında yapılan incelemede Kemer-Edremid tezgâhında icrâ edilen inşâ faaliyetleri hakkında genel-geçer yorumlarda bulunmaya yarayacak derecede arşiv belgelerine rastlanmamıştır. Bu nedenle tezgâhta belirli bir zaman dilimi içinde gemi yapımının sıklığı, tezgâhın potansiyeli, inşâ edilen gemilerin çeşitleri ve niteliklerinin bölgedeki diğer tezgâhlarla karşılaştırılması gibi hususlara değinilmemiştir. Zirâ bu sorular başka bir incelemenin konusunu teşkil edecek özelliktedir. Burada sadece tezgâh hakkında tanıtıcı bilgiler verilerek, donanma açısından taşıdığı önem ve gördüğü bazı hizmetlerden kısaca bahsedilmiştir. Ancak, Kemer-Edremid tezgâhının, yakınında bulunan ve kendisinden fazla nüfus barındıran Midilli ve Edremid tezgâhlarıyla, başkente daha yakın olan Biga-Kemer gibi tezgâhlara göre, ikincil derecede öneme sahip olduğunu düşünebiliriz. Bununla beraber altını çizdiğimiz gibi, arşiv belgeleri ve diğer kaynaklar üzerinde yapılacak geniş kapsamlı çalışmalar ile bu noktalar aydınlatılacaktır.

\subsection{Kemer-Edremid Kazâsından Donanma İçin Kereste Temini}

Buharlı gemilerin inşâsına dek Osmanlı donanmasının temel gemi malzemesinin ahşap olduğuna, devlet tarafindan tespit edilen kurallar ve sinırlar çerçevesinde ormanlardan kesilen kerestelerin ahşap malzemeyi teşkîl ettiğine yukarıda değinilmişti. Bu çerçeve kapsamında gemi inşâsında kullanılan kereste iki yolla sağlanmaktadır. Bunlardan ilki ocaklık olarak alınan kereste, ikincisi ise ocaklık harici satın alınan kerestedir. Ocaklık kereste alımına göre reâya her sene Tersâne-i Amire'de yeniden inşâ edilecek bir kadırga için (incelediğimiz dönemde kalyon, firkateyn ve diğer gemilere) yeterli miktarda keresteyi avarız vergileri karşıllı̆ında kesip hazırlamakla yükümlü idiler. Örneğin Kocaeli havâlisinden alınan ocaklık kereste her 
bölge için tayîn olunan avârız miktarına göre akçe şeklinde belirtilmekte idi. Cinsi, adeti ve mîrî (devletçe belirlenen) fiyatı ayrıca kaydediliyordu. Temini istenen kereste avârızları karşılığında alınan bir hizmet olsa da devlet ocaklık kereste fiyâtının sadece bește birini ödemekte, geri kalanını ise yine avârız olarak reâyadan talep etmekte idi. Ocaklık bölgelerden mîrî fiyatla satın alınan kereste tüccar fiyatı ile satın alınan kerestenin beşte biri oranında daha ucuz idi. (Bostan, 2003: s.102-109)

Ormanların kullanımlarına göre çeşitli sınıflandırmalara gidilmesi ve ocaklık sistemi gibi hususlarla birlikte, devletin bazı mal ve hizmetlerde izlediği ekonomik politikalar, kereste tedarikinde etkin olan diğer belirleyici unsurdur. Ekonomik olduğu kadar siyasî ve askerî nedenlerden de kaynaklanan bu politikaların ana gayesi evvelâ devletin çıkarını sağlamak ve stratejik hedeflerin sekteye uğramasını engellemekti. Kalabalık bir nüfûsu barındıran başkent İstanbul'un gıda gereksiniminin sağlanmasında devletin tutumunu şekillendiren ilkeler arasında bulunan fiskalizm (iaşecilik) prensibi, Genç'in ifadesiyle Osmanlı ekonomik dünya görüşünün önemli ilkelerden birisiydi. Bu ilke doğrultusunda yurt içi ihtiyaçların tümü karşılandıktan sonra fazla kalan mal varsa onun ihraç edilmesine müsaade edilmekte, üretimin temel hedefi yurt içi ihtiyaçların karşılanmasına hasredilmekteydi. Devlet aynı zamanda bu ilke doğrultusunda ihtiyacı olan ürün ve hizmetlerin karşılanmasında mirî mübâyaa sistemi olarak adlandırılabilecek bir alım usulü takip etmekte idi. Fiskâlizm ilkesinin etkisi altında şekillenen resmî alım yöntemi veya mirî mübayaa sistemi, devletin yönettiği kitleye masrafları karşılığında yapacağı ödemeleri kısıtlamaya çalışmasının yanında, hizmet ve ürünlerin temînini genellikle piyasa fiyatlarından, hatta bazen üretim fiyatlarından bile ucuza temin etmesini sağlamak için koyduğu zorunluluk şeklinde nitelendirilebilecek bir sistem olarak değerlendirilmektedir. Barış zamanlarında halk üzerinde fazla etkisi olmayan bu politika nedeniyle ekonomik kriz ve savaş dönemlerinde geniş miktarda zanaatçı kitleleri ve tüccarlar devletin sürekli artan talepleri nedeniyle sıkıntı yaşayabilmekteydiler. (Genç, 2009: s.52)

Osmanlı imparatorluğu'nun mirî mübâyaa sistemi doğrultusunda halktan ucuz fiyata almaya çalıştığı ve resmî talep karşılanmaksızın ihrâcını yasakladığı ürünlerden birisi de keresteydi. Donanma için vazgeçilmez bir malzeme olan kerestenin istenildiği zaman yeterli şekilde elde edilebilmesi devlet için oldukça önemli bir konuydu. Zirâ sık sık çıkan savaşların yanı sıra, sürekli yenilenmek zorunda olan donanmanın varlı̆̆ 1 devamlı surette kereste ihtiyacını zorunlu kılıyordu. Mîrî mübayaa sistemi icâbı devlet savaş zamanlarında artan ölçüde ihtiyaç duyduğu kereste, dokuma, iplik, deri ve demir gibi malları piyasa fiyatından çok düşük, bazen yukarıda da ifade edildiği gibi maliyetin de altında kalan bir rakamda talep ediyordu. Bununla birlikte tüccarlar tarafından gizlice yürütülen özel teşebbüs ile çatışan devletin istekleri kerestenin devletten habersizce kesilerek kaçırılması sonucunu doğuruyordu. Gemi inşâatında kullanılan kerestelerin yabancı ülkelere satılmaması için gerekli tedbirler alınıyor, hatta ihraç için yüklenen kerestelere el dahî konulduğu görülüyordu. Ülke dışına ve tüccarlara kereste satışını yasaklanmaktaydı. Bunlarla birlikte ocaklık kereste istenen reayadan bazı zamanlarda hoşnutsuzluk görülmekteydi. Ancak devlet tarafından bu konuda kesinlikle müsamaha gösterilmiyordu. Bir takım vergiden muâf zümreler devletin ocaklık harici kereste satın almasına katılmak istemedikleri gibi, bazı köylülerde hazırladıkları keresteleri iskelelerden satmakta idiler. (Genç, 2009: s.264; Bostan, 2003: s.110-111)

Bir nevî ülkedeki kereste depolarından birisi olarak niteleyebileceğimiz Kazdağları'nın çevresinde yer alan kazâlara da bu politikalar kapsamında çeşitli uyarılar yapılmaktaydı. 9 Şabân 1228 /7 Ağustos 1813 tarihli bir belgeye göre, kerestelerin Tersâney-i Amire için ayrılan yerlerden dişarıya ihracının yasak olmasına rağmen Edremid Voyvodası'nın Cezayîr-i Garb'e sevk edilmek üzere birkaç yüz kıta kebîr (büyük) ağaç kestirerek iskeleye naklettirmiş olduğu haber alındığından, hazırlattığı kerestenin Tersâney-i Amire için celbi emredilmişti. (EŞS.1247/72-b-3.) 25 Şâban 1240 /14 Nisân 1825 tarihinde ise Akdeniz'de dolaşmakta olan eşkıya teknelerinin adalardan ve sahil kazâlarından hile ile kereste mühimmat aldıklarının öğrenilmesi nedeniyle, gerek İslam gerekse müstemen tüccarlarının Anadolu sahillerinden 6 ay boyunca kereste ve diğer eşyaları tedârik etmeleri yasaklanmıştı. Patlak veren Rum isyanı nedeniyle Akdeniz adalarına eşkıyaya karşı harekât yapmak üzere gelen Mısır Donanması da gemilerini tamir etmek için kereste talep etmiş, ancak yasak nedeniyle talepleri reddedilmişti. Bu noktada Mısır donanması tarafından alınacak kerestenin gemilerinde kullanılacağı kanâati hasıl olduğundan, yasağın devamıyla birlikte kendilerine gereken yardımın yapılmasına izin verildiği belirtilmekteydi.(EŞS.1249/65-a-2) Şeriye sicillerinden tespit edilen bu tür 
örnekler kerestenin devlet tarafından ne derecede önem taşıdığını yansıtması açısından dikkât çekmektedirler.

Kemer-Edremid kazâsı, donanma için talep edilen keresteleri Kazdağlarından elde etmekteydi.Zengin ormanlara sahip, Biga Yarımadasının güney kısmında, Edremit körfezinin kuzeyinde, güneybatı- kuzeydoğu yönünde yükselerek $55 \mathrm{~km}$. boyunca uzanan bir dağ zinciri olan Kazdağlarının yamaçlarında mevcut ağaç türleri çeşitlilik göstermektedir. Bunlar arasında meşe, kayın, kızılçam, ardıç, karaçam ve göknar yaygın türlerdir. Çağlar boyunca çevre bölgelere yapı malzemesi, tekne kerestesi ve yakacak temin eden Kazdağları antik Truva uygarlığının ekonomisi için de önem taşıyan bir yükselti olma özelliği taşıyordu. (Erel-Adatepe, 2013: s.13) 1305/1888 tarihli Karesi Salnâmesi’nin verdiği bilgilere göre göre Kazdağları silsilesi, At kayası, Çam Eleği, Karanlık Dere, Açöldüren ve Asar Dağı gibi kıtalara ayrılmıştır. Bunlardan yalnızca Asar Dağı sahile uzak ve yolları sarp olduğundan kereste temin ve ihrâcatının az olduğu bir kısımdı. Bu ormanlarda $a k$ çam, kara çam, klzıl çam ve balsara çamı gibi çam çeşitleriyle, gürgen, köknar ve meşe ağaçları mevcuttu. Yine aynı salnâmeye göre Kemer-Edremid kazâsında Karadere mevkîinde 100.000 dönümlük bir orman bölümü mevcut olup, sahile uzaklığı 8 ila 10 saatlik bir mesafedeydi. Ak ve kara çam ağaçlarını barındıran bu ormandan elde edilen kereste birlikte bir su hızarı sayesinde mazı ve çam kabuğu gibi yan ürünler sağlanmaktaydı. İç tüketime hitap eden bu ürünler aynı zamanda civardaki sahillere de ihrac edilmekteydi. (Karesi Vilâyetine Mahsus Salnâme, 1305: s.74-75-76) Balıkesir ormanlarında bulunan ağaç çeşitleri arasında ise ak meşe, kara meşe, kızıl meşe, ardıç, gürgen, kestane, palamut, kayın, kızılkavak, 1hlamur, çam, kızılağaç, pirnar, çınar, kocayemiş ve fındık gibi çeşitler mevcuttu. Ancak bu ormanlardaki ağaçlardan elde edilen kereste üretimi, cumhuriyetin ilk yıllarına gelindiğinde oldukça azalmıştı. Bu yıllarda vilayet ormanlarından tam olarak yararlanamamakta ve Bandırma başta olmak üzere diğer kazalar kalas, kereste ve tahta gibi ihtiyaçlarını Romanya'dan sağlamaktaydı. (Balıkesir Ticaret ve Sanayı̂ Odası Salnâmesi, 1926: s.5.)

Bostan, Kazdağları ve çevresini Biga, Çan, Kalâ-i Sultanîye ve havâlisine tahsis edilmiş ocaklık kereste merkezi kategorisine almaktadır. Ayrıca XVII. yüzyılda buradan Tersâne-i Amîre için 10 kadırgaya yetecek kadar kereste tedarik edildiğini belirtmektedir. ( Bostan, 2003: s.112; Bu bölgeden ocaklık olarak alınan kerestenin 1657-96 yılları arasındaki tutarları için bkz. Bostan, 2003: s.113-Tablo-XXX; ) Ocaklık kerestenin ormanlardan kesilmesi şu şekilde yapılmakta idi. Tespit edilen kereste miktarı bir mübaşir vasıtasıyla ait olduğu kazâya gönderiliyordu. Bunun üzerine reaya aralarında işi gerçekleştirecek olanları belirliyordu. Daha sonra yapacakları iş karşıllı̆ında mübaşirden para alarak hizmeti yerine getirmeyi taahhüd ediyorlardı. 1644 yılında donanma için Balıkesir'den tedarik edilecek olan 8 adet koğuş-1 paşa, 12 koğuş-1 kadırga, 60 vürdinar-1 çam ve 15 çıbuk-1 çam (çubuk-1 çam) için mübaşir Hasan Ağa ile birlikte 7.515 akçe gönderilmiş ve bu para mahkeme huzurunda keresteyi kesip nakledecek 4 mekkâriye (taşımacı) verilmiş, onlar da bu hizmeti yerine getirmeyi taahhüd etmişlerdi. (Bostan, 2003: s.114)

Kemer-Edremid'den talep edilen kereste çeşitleri arasında arşiv vesikâlarından tespit edebildiğimiz kadarıyla ilk sırada lata çam (latay-ı kebîr) ve koğuş çam türlerindeki keresteler gelmektedir. Bu kereste çeşitleri adlarından da anlaşılacağı gibi çam ağaçlarından elde edilmekteydiler. Örneğin lata kerestesi kızıl çam ağacı mamûlüydü. Kızıl çamdan lata cinsi ile birlikte, dörtlük, beşlik ve azman gibi diğer çeşit keresteler de elde ediliyordu. Çam keresteleri ahşap binalarda, köprülerde, binaların pencere çerçevelerinde, tavan tahtalarında, dikmelerinde ve kapılarda kullanılmaktaydı. Örneğin XIX. yüzyılın sonlarında dahi Gönen kazâsındaki akmeşe, kızılmeşe ve çam ormanlarından gemi ve binâ inşâatlarında yararlanılıyor, travers ve koçu tahtası gibi ahşap mâmuller üretildiği gibi, Tersâne ve Tophâne-i Amîre'ye kereste ve koçu tahtası ihraç ediliyordu. (Berkel, 1957: s.60-61; Karesi Vilâyetine Mahsus Salnâme: 1305, s.71-72;)

Kazdağları çevresindeki kazâlara tarh edilerek istenilen yere gönderilecek kereste miktarlarında genel bir standartın varlığından söz edilebilir. 5 Zilkâade 1211 / 2 Mayıs 1797 tarihli bir sicil kaydına göre, adı geçen havâliden Tersâne-i Amire'de inşa edilerek denize indirilen üç-anbarlı bir firkateyn için 500 adet latay-1 kebîr, 1000 adet koğuş çam talep edilmişti.15 C.Evvel 1215/4 Ekim 1800'de Donanmay-1 Hümâyun kalyonlarının ihtiyacı için yine 500 latay-1 kebir ve 1000 adet koğuş çam, 18 Safer 1225 / 25 Mart 1810'da ise aynı şekilde 500 adet latay-1 kebîr ve 1000 adet koğuş çam istenilmişti. 21 Zilhicce 1233 / 22 Ekim 1818 
tarihinde "Kazdă̆l ve havâlisinden mut'ad olduğu üzere" 500 latay-1 kebir ve 1000 adet koğuş çam alınacağ1 ifade edilmişti (BRHŞS.1094/44-b-2, 57-a-1, 105-a-2, 1095-A/7-b-1, EŞS.1247-16-a-1; İlerleyen tarihlerde de tedarik edilen kereste oranlarının aynı olduğu görülmektedir. 6 Zilkâade 1242 /1 Haziran 1827'de 500 latay-1 kebir, 1000 koğuş çam Tersâne-i Amire'ye gönderilmek üzere kazâlara tevzî edilmiştir. BRHSSS. 1095-A/48-b-2)

Tersane-i Amire'ye gönderilecek keresteler, diğer bazı yükümlülüklerde olduğu gibi Kemer-Edremid'e genellikle Edremid ile ortak şekilde tarh edilmekte idi. Bu nedenle her iki kazanın sicillerinden donanma için alınan kerestelerin miktarlarını tespit edebilmekteyiz. Bu oranları Kemer-Edremid açısından genel olarak değerlendirdiğimizde, kazâ hissesine isâbet eden rakamların, küçük farklar dışında hemen hemen sabit oluşu da dikkat çekicidir. Örneğin 5 Zilkâade 1211 / 2 Mayıs 1797 tarihinde Tersâne-i Amîre'de yeni inşa edilen üç-anbarlı firtkateyn için gereken keresteden Kemer-Edremid'e 72 adet latây-1 kebîr ve 143 adet koğuş çam, 5 Şabân 1215 / 22 Aralık 1800 tarihli bir tevzîide ise aynı miktar kereste talebinden Kemer-Edremid'e 71 adet koğuş, 143 adet latay-1 kebîr isabet etmişti. Bu tevzîide Kemer-Edremid gibi Edremid hissesine de aynı şekilde 72 latay-1 kebîr ve 143 koğuş çam kerestesi tarh edildiği görülmektedir. 18 Safer 1225 / 25 Mart 1810 tarihinde Kazdağ 1 civarından alınacağ Edremid'e 143 koğuş, 71,5 adet lata isabet etmişti. (BRHŞS.1094/44-b-2, 57-a-2, EŞS.1247/16-b-2; 5 Şabân 1215 / 22 Kasım 1800 tarihli bir deftere göre diğer Karesi kazâlarına isabet eden kereste oranları şunlardır: Biga 143 koğuş 71 latay-1 kebîr, Çan 143 koğuş 71 latây-1 kebîr, Ezine 143 koğuş 71 latây-1 kebîr, Bayramiç 143 koğuş 72 latay-1 kebîr, Tuzla 143 koğuş 72 latay-1 kebîr. BRHŞS. 1094/57-a-2)

Kemer-Edremid ve Kazdağları yöresindeki diğer kazâlar yalnızca Tersâne-i Amîre için değil aynı zamanda başta yakın çevredeki diğer gemi inşâ tezgâhları olmak üzere farklı yerler için de kereste tedarikiyle yükümlü kılınıyorlardı. Kazânın kereste gönderdiği yakın çevredeki gemi inşâ tezgâhları arasında bilhassa Midilli ve Biga-Kemer gibi yerlerin ön plana çıktıkları görülmektedir. 23 Receb 1224/M. 3 Eylül 1809 tarihli bir belgede "Midilli sahasında 39 zira olarak inşâsına irâdey-i senîyyem taallük eden bir kita firkayteynin lazımesinden olan 3.308 kita ecnâs kerestenin Midilli ceziresinden kat'ı içün bundan akdem sûret-i emr-i şerîfim isdâr ve itâ olunmuş olub, ancak zikr olunan keresteden çam ecnâs kerestesi Midilli ceziresinde bulunmayub, sâbıklarda dahî Biga ve Çan ve Kemer-Edremid havalilerinde kat ve nakl oluna-geldiğinden" ifadesi Midilli adasında yapılan gemilerin kerestelerinin Kazdağları civarından tedarîk edildiğini açıkça göstermektedir. (EŞS. 1247/4-a-3; Diğer bir belgede ise "Midilli Nâzırı Es-Seyyîd Ömer dâme mecdûhu marifetiyle Midilli sahâsında inşâları fermânım olan iki kıtâ Kırlangıç sefinelerine puşî́deli-çün tahtalık çam koğuş ol-tarafda bulunmadığına binâen.."'şeklinde bir ifade ile Midilli sahasının çam kerestesi hususundaki eksikliği belirtilmektedir. BOA.C..BH..195-9155-1.)

Osmanlı donanması açısından önemli bir gemî inşâ merkezi olan Midilli'nin kereste hususundaki eksikliği aynı bölgedeki Kemer-Edremid ve Edremid gibi kazâların desteğiyle gideriliyordu. 3 Muharrem 1176 / 25 Temmuz 1762 'de Midilli'de inşâ edilecek bir kalyon için gereken 191 adet koğuş ve 60 adet lata çam kerestelerinin toplam masraflarının Kemer-Edremid'in 242 hanesi arasında taksim edildiği defter bu durumu açıkça göstermektedir. 20 R.Evvel 1202/30 Aralık 1787 tarihinde ise Midilli Nâzırı tarafından inşâ ettirilecek iki kırlangıç gemisinin puşideli tahtaları için Kemer-Edremid'den 150 adet latay-1 kebîr ve koğuş çam kerestesi alınmasına karar verilmişti. Yine yukarıda örnek gösterilen 23 Receb 1224/3 Eylül 1809 tarihli talepte bahsi geçen firkateyn için gereken 3.308 kıt'a keresteden 307 kıta latay-1 kebîr, 785 kıtâ koğuş çam ve 400 adet koğuş taban kerestesinin Kemer-Edremid, Çan, Biga ve bölgedeki diğer yerlerden tedarikine karar verilmiştir. 5 Muharrem 1243 /29 Temmuz 1827'ye gelindiğinde Nâzır Mustafa Ağa marifetiyle Midilli sahâsında inşâ edilecek firkateynin 1200 kıta kerestesinin Edremid ve Kemer-Edremid'e tarh edilmesi kararlaştırılmış ancak limanın dolması nedeniyle bu girişimden vazgeçilmişti. Sonradan fırkateyn yerine 40 zira tûl ve 32.5 kadem arzında iki adet korvet inşâsı uygun görüldügüünden firkateyn tertibi olan 140 latay-1 kebîr ve 900 adet koğuş çam kerestesinin 858 adedinin Kemer-Edremid ve Edremid kazâlarının 1242/1826, 1243/ 1827 seneleri tertiplerinden, kalan 182 kit'anın ise eski senelerin kereste bakayalarından karş1lanmasına karar verilmişti. (BRHŞS.1094/24-a-1, a-2, BOA.C..BH..195-9155-1, ESSS. 1247/4-a-3, BRHSSS.1095-A/49-a-3; Midilli sahası için hazırlanan keresteler Midilli Nâzırına teslim edilerek Midilli ve Yunda adalarından gelen gemilerle adaya sevk edilmişti. EŞS.1247/24-b-4) 
Kemer-Edremid'in Midilli ile birlikte kereste sağladığı diğer bir mahal ise Marmara denizi sahilinde bulunan Biga-Kemer sahâsıdır. Safer 1219 /M.Mayıs-Hazîran 1804 tarihinde daha önce Kemer sahâsında inşa edilerek denize indirilen kalyonun yerine Biga Mütesellîmi Hadımzâde Osman Bey marifetiyle inşâ edilecek 57.5 zir'alık yeni bir kalyonda kullanılmak üzere, Kemer-Edremid kazâsından toplam 453 adet çam kerestesi alınmıştı (BRHŞS.1094/67-a-2.)

Kazdağ 1 ve havâlisinden alınan keresteler sadece gemi inşâsında değil, diğer askerî ihtiyaçların giderilmesi için de kullanılmakta idi. 28 Şâban 1207 /10 Nisân 1793 tarihinde Biga ve Kemer-Edremid kadılarına gönderilen bir emirde, Gelibolu Baruthânesi'nde İngiltere ve Felemenk (Hollanda) perdahtı üzere imâl edilecek barutun konulacağı fiçıların yapımı için Biga ve Kemer-Edremid dağlarından 40.000 adet varil tahtasının kesilerek Gelibolu'ya gönderilmesi istenmişti.1223/ 1808 y1lında ise, Limni kalesindeki top ve havânların araba ve kundaklarında kullanılmak üzere Kemer-Edremid'den Karaağaç cinsi kereste talep edilmiş ancak, bu cins kerestenin tedarik edildiği ağacın kaza civarında mevcut bulunmamasından dolayı merkezin talebi yerine getirilememişti. (BOA.C..AS.465-19419,1116-49436)

Devletin belirli miktardaki kerestenin dağlardan kesilerek hazırlanması ve hızlı bir biçimde gönderilmesi hususundaki emirleri her ne kadar halk tarafindan yerine getirilmekte ise bu hususta zorluk yaşandığ 1 görülmektedir. Kemer-Edremid ve diğer kazâlar bazı zamanlarda kereste tedariği konusunda devletten af talebinde bulunuyorlardı. Bilhassa halkın karşılamak zorunda olduğu diğer yükümlülükler bu hususta etkili olmaktaydı. 25 Zilhicce 1225 / 21 Ocak 1811 tarihinde Kazdağ civarındaki kazâlarla birlikte Biga ve Çan kazâları ahalileri, Ruslar üzerine yapılacak seferin yaklaşması nedeniyle vergilerin çokluğundan ve diğer sebeplerden zor duruma düşmeleri nedeniyle Tersane-i Amire'de inşâ edilecek bir firkateyn için istenen kerestenin affını ricâ etmişlerdi. Ancak merkezden verilen cevapta, inşası düşünülen firkateynin forsalarının dahi toparlanmaya başlandı ğı, adalardan celbedilen amelenin atıl bir vaziyette bekledikleri ve inşâata yakında başlanacağı (bu seneki forsaları va'z olunub dolmağda olmağla lata ve koğuşa eşedd-î ihtiyaç ve bahusus adalardan celb olunan amele atıl ve inşâsı karîn-i zaman olduğun) gibi gerekçeler öne sürülerek halkın talebi reddedilmişti. (EŞS. 1247/ 14-a-1; Aynı isteği içeren başka bir emir için bkz. EŞS. 1247/23-a-1.)

\subsection{Kemer-Edremid'den Tedarik Edilen Bazı Kereste Cinsleri ve Fiyatları}

Lata ve koğuş çam ile birlikte, Kemer-Edremid kazâsından donanma için alınan keresteler arasında farklı isim ve türlerde olanlar bulunmaktadır. Bilindiği gibi Osmanlı gemilerinin inşâsında kullanılan çok sayıda kereste cinsi mevcuttur. Örneğin, XVII. asırda bu amaçla tedarik edilen 76 çeşit ocaklık kereste adı tespit edilmiştir. Devlet tarafından alımı yapılan keresteler sağlandıkları bölge ve gemi inşasında kullanıldı̆̆ kısımla ortak bir biçimde adlandırılıyordu. Bu şekilde isimledirilen kereste türleri arasında kara sağır çam tahtası, çifte kanatlık, bostan oluğu, çifte bordalık, çifte çam tahtasl, çifte kalas, oniki arşın lata, on iki arşın kebir çam, çifte mane, kestane ağacı tahtası, Rumeli omurgası, Bartın omurgası, Kidros omurgası, Bartın kanatlığı, Karasu tahtası, Fındıklı dolabı, Fıstıklı koğuşu, asdar, barbelik, barbe-i kebîr, baryalık-ı kebîr, bedel koğuş kabll, bedel koğuş çam kabll, çubuk çam, diyame-i să̆îr, diyame-i kebîr, döşek, döşek mîşe kütük, ecnâs-ı çam, pelenk, findık, findık çubuğu, katene, kazıklık, kızak koğuş, koğuş-ı çam, kütük, kütük-i mîşe iskelelik, ırgad-ı sağîr, ırgad-ı manula, latakna, levm-i yar, makaralık-ı kebîr, makaralık-ı sağîr, makas direk, mertanlık kürek, mülk omurga, tahtalık, tahtalık-ı çam, taslak kürek, tiyame-i sağîr üsküce, küyeşte varyozluk, varyalık, yarpalık, seren direği, seren-i sağîr, tirhandil-i kebr-î çam, yeke-i dümen, ser kütük, çatal bükme, çatal kazık, kemerey-i latay-ı kebîr çam gibi isimlerle anılan çeşitler bulunmaktadır. Yine, 1783 tarihiyle 55.5 ziralık bir kalyon için gereken keresteler arasında bodoslamay-ı baş, bodoslamaykıç, parey-i bodoslamay-ı baş, asdar-l bodoslamay-ı baş, asdar-ı bodoslamay-ı kıç, akreb-i baş, kanad-ı kalyon, parey-i kanad-ı kalyon, praçol-ı akreb-i kıç, karina, asdar-ı karina, ve bükme çatal gibi kereste isimlerine rastlanmaktadır. (Bostan, 2003: s.104; Zorlu, 2008: s.19-20-21; Kocaeli ve civarından elde edilen ocaklık kerestelerin cins ve isimleri için Bostan, 2003: s.105-106- Tablo XXIX ; Biga ve çevresinden elde edilen ocaklık kerestelerin cins ve isimleri için ise Bostan, 2003: s.114-Tablo-XXXI, s.115 Tablo-XXXII; Osmanlı döneminde inşâ ve mimarîde kullanılan ahşap çeşitleri ve diğer malzemeler için Sönmez, (1997) Osmanlı Dönemi Yapı ve Malzeme Terimleri Sözlüğ̈̈, İstanbul: Yapı Endüstri Merkezi Yayınları) 
Kemer-Edremid'ten tedarik edilen farklı çeşitlerdeki kerestelerin isimlerini Mısır donanmasına yardım yapılması hakkında gönderilen bir emir vesilesiyle öğrenmekteyiz. 25 Şabân 1240 /14 Nisân 1825'te Rum isyânını bastırmak amacıyla Mora'ya giden Mısır donanmasına yardım edilmesi emriyle İzmir'den gelen İngiliz ve Avusturya bandıralı gemilere yüklenerek gönderilen kereste çeşitleri arasında Türkmen tahtası, çatma direği, dörtlü tahta, pencere kanadl, Mısır ă̆act, söge, çatı direği, doğrama, kaydırma doğrama, yalancı nerdübanlık, kabuluk tahta, azman, 16'llk (veya 16'll) ăgaç, 12'lik ă̆aç, 8'lik ağaç, 4'lük ă̆aç, bordina ve çıra gibi kereste ve ahşap çeşitleri mevcuttu. ( Çıra kantar hesabı üzerinden alınmıştır. EŞS.1249/ 65-a-2, 77-a-3, a-4, a-5 ,a-6, 77-b-1, b-2.) Kerestelerin isimleri gibi ölçüm ve biçimlendirilmeleri de çeşitli isimlendirmelerle yapılmaktaydı. Donanma gemileri inşasında kullanılan zirâ, arşun, kadem, karlş ve kulaç ve umk aynı zamanda ağaç ticaretinde de kullanılan temel ölçü birimleriydi. Sicillerde karşılaştığımız ölçü birimleri arasında ise baş, parmak, kalınlık, yakalık gibi birimleri bulunmaktadır. (EŞS. 1248/72-a-6, 1247/41-b-3. "beher kitası tûl'en on altı zira ve yakalı̆̆l ve kalınlığı on yedişer baş"1247/41-b-2)

Kemer-Edremid ve Edremid'den devlet tarafindan alınan kerestelerin resmî fiyatları üzerinde durulması gereken diğer bir husustur. Şeriye sicillerinde kazâya tarh edilen vergilerin bölüşüm oranlarını belirten tevzî defterlerine kerestelerin miktarıyla birlikte adetleri üzerinden belirlenen fiyatları da kaydedilmektedir. İlk olarak, her yıl düzenli olarak talep edilen lata ve koğuş çam kerestelerinin fiyatlarından bahsedebiliriz. 5 Zilkâade 1211/2 Mayıs 1797 tarihli bir örneğe göre, latanın adedi 280 , koğuş çamın adedi ise 200 paradır. Aynı fiyatlar 15 C.Evvel 1215/4 Ekim 1800 ve 18 Zilkâade 1218/29 Şubat 1804 tarihlerinde yapılan alımlarda da karşımıza çıkmaktadır. Bu tarihlerde benzer şekilde, bir adet lata kerestenin bedeli 280, koğuş çam kerestenin ise 200 paradır. İlerleyen yıllarda lata ve koğuşun alım fiyatlarında yukarıdaki örneklerdeki oranlara nazaran bir artış olduğunu söyleyebiliriz. Safer 1225/Nisân-Mart 1810 tarihli bir tevzîide lata çam kerestesi 340, koğuş çam kerestesine ise 240 paralık fiyat biçilmiştir. Aynı fiyatın 21 Zilhicce 1233/22 Ekim 1818 tarihinde de geçerli olduğu görülmektedir. Böylece XIX. yüzyılın ilk çeyreğinde lata ve koğuş çam kerestelerinin devletçe belirlenen fiyatlarında XVIII. yüzyılın sonlarına göre toplam 100 paralık bir artıştan söz edebliriz. (BRHŞS.1094/44-b-2,57-a-1,78-a-4, EŞS. 1247/16-a-1, BRHŞS.1095-A/7-b-1.)

Lata ve koğuş çam kerestelerine ait fiyatlarla ile birlikte farklı cins kerestelerin fiyatlarına da şeriye sicillerinde rastlanmaktadır. Safer 1219 / Mayıs-Hazîran 1804 tarihinde Biga-Kemer sahasında inşâ edilecek bir kalyon için gönderilecek bir omurga çam kerestesi 1.000 paralık değere sahiptir. 1222 / 1808 senesinde Kazdağ 1 ve havâlisinden tedarik edilerek inşâ edilecek üç mîrî kalyonda kullanılacak kemerelik ve omurga çamların fiyatlarının da yine 1000'er para olduğu görülmektedir. Bu fiyata bakarak, omurga çam kerestesinin diğer kerestelere nazaran yüksek değerde olduğunu söyleyebiliriz.Yine aynı kalyon için talep edilen asdar omurga çam 400 para, sarı çam 200 para, vürdinar çam ve çubuk çam ise 100'er paralık değere sahiptiler. (BRHSSS.1094/67-a-2, ESSS. 1247/41-b-2,b-3.) 1 Muharrem 1242/5 Ağustos 1826 tarihinde 1250 numaralı Edremid şeriye siciline kaydedilen bir emirde kerestelerin müstemen taifesi başta olmak üzere satılması yasak olan yerlere verilmemesi için yapılan düzenleme kapsamında, bazı kereste çeşitlerine ve bunların adetleri üzerinden tahsîl edilen gümrüklerin miktarlarına dair tafsilatla karşılaşmaktayız. Bu vesile ile birlikte devletin tespit ettiği resmî kereste fiyatlarını öğrenebilmekteyiz. Buna göre resm-i gümrük hariç çubuk, tahtalık ve azman ăgaç 22 para, să̆îr lata ăgaçlik 1.5 para, vasat lata ăgaç 3 para, 8'lik ăgaç 6 para, 12'lik ağaç 9 para, 16'llk ağaç 12 para, ak doğramanın 100 adedinden 26 para, yarı tahtanın 1000 adedinden 3 guruş, Türkmen tahtasından 1 para, çadır direği'nden 1 para, Karaman-ı kebîr tabîr olunur makaslık ağaç'tan 1.5 para, vasat Karaman, sağîr Karaman ve sakiz ağacından l'er para resm-i mîrî alınmasına karar verilmişti. Kereste gümrüğü aynı zamanda iltizâm yöntemiyle taliplerine kiralanmakta idi. Tanzimât sonras1, 19 Receb 1262 /13 Temmuz 1846 senesinde Edremid ve Kemer-Edremid kereste gümrüklerinin İzmir muhassılına deruhde edildiği görülmektedir.(EŞS.1250/5-a-1, BOA.İ.MLV.79-1551)

Kereste tedariki konusunda halk tarafından karşılanan diğer bir yükümlülük ise kesilip nakledilmesi hizmeti için harcanan paranın yine ocaklık dahîlinde akçey-i bedel-i muâvenet-i kerestehâ adıyla ödenmesiydi. Bostan'ın belirttiğine göre toplamda 500.000 akçe tutarındaki bu meblağ, keresteyi taşıma ve kesme işlemlerini yapan reâyaya verilmekte, beşte biri de mübaşir maaşı olarak ayrılmaktaydı. (Bostan, 2003: s.114-115) Bu yükümlülük ocaklık kapsamındaki diğer hizmetler gibi, avârız türünden bir vergi sıfatını taşımaktaydı. Bir kazâya tarh edilen bedel-i muâvenet akçesi sicillere kaydedildikten sonra şehrin mahalle ve 
köylerine hane başına tevzî edilmekteydi. Örneğin, 1098 /1686-87 senesinde Bursa'da hane başına 50 akçesi muâvenet bedeli, 15 akçesi ise harc-ı tersâne olmak üzere 65'er akçe vergi tarh edilmişti. (Çiftçi, 2000: s.249, 254) Kemer-Edremid șeriye sicillerinde sadece bedel-i muâvenet adıyla tevzî edildiğini gördüğümüz bu vergi kapsamında, 17 Muharrem 1225 / 22 Şubat 1810 tarihinde Biga sancağı kazâlarından merkez Biga ile birlikte Lapseki, Balya, Güvercinlik, Ezine, Çan ve Eyne, Karesi kazâlarından Kemer-Edremid, Fart ma Şamî, Balıkesir, Bigadiç, Başgelembe, İvrindi, Ayazmend, Kozak, Hüdavendiğar kazâlarından Gönen, Manyas, Mihalıç, Kirmastı, Edincik, Bayramiç, Tuzla ve Kepsut kadılarına gönderilen emirde 1 yükü mübaşîr mâaşı olmak üzere toplam 5 yük akçe bedel-i muâvenet tayîn edilmişti. Tahsil edilecek 4 yük akçenin 1.400 kıtâat (adet) koğuş-1 paşa, koğuş-1 kadırga, çubuk-1 kadırga gibi kerestelerin kesilmesi için ocaklık olarak alınacağı açıkça belirtilmektedir. Belgede ayrıca kadırga inşâsı maksadıyla kereste talebi terkedilse dahi, Kemer-Edremid hissesine isâbet eden bu meblağın her sene alınmaya devam edileceği vurgulaniyordu. (BRHŞS. 1094/102-a-3.)

Bedel-i muâvenet akçesi adıyla anılan 5 yük yani 500.000 akçelik meblağdan, Kemer-Edremid hissesine isâbet eden oran 1142 /1729-30'da 16.000 akçe, 28 C.Evvel 1208 / 26 Aralık 1793 tarihinde de aynı șekilde yine 16.000 akçe olarak görünmektedir. Akçe cinsinden alınan bedel-i muâvenet birlikte guruş cinsinden de karşılanan bedel-i muâvenete dair örnekler görülmektedir. 1173/M.1759-60 tarihli bir tevzîide imdad-1 hazerîye ve bedel-i avârız taksîtleriyle birlikte bedel-i muâvenet akçesinin taksîdi olarak kaydedilen 133 guruşluk bir meblağ ile karşılaşmaktayız. İlerleyen tarihlere gelindiğinde, bedel-i muâvenet miktarının değişmediği görülmektedir. 24 Şevvâl 1237/14 Temmuz 1822 tarihinde yapılan bir tevzîide bedel-i muâvenet akçesi olarak yine toplam 5 yük akçe tahsîl edileceği önceki tevzîilerdeki benzer ifâdelerle belirtilmiştir. (BRHŞS.1093/55-b-1,1094/20-b-2. "Seney-i mezbûra mahsûben bedel-i muâvenet emri cem ve tahsîli bâbinda vürûd. Kazây-ı Kemer-Edremid taksit-I / 133 guruş” BRHŞS.1094/ 71-b-1, 1095-A/16-a-2)

Bedel-i muâvenet ile birlikte, kesim ve nakliye işlemleri için ayrıca kat'iye ve naklîye adlarıyla başka kalemlerin de tevzî defterlerine işlenerek kaza hanelerine bölüştürülmesi dikkat çekicidir. Bu kalemlerin bedel-i muâvenetten ayrı mahiyette oldukları anlaşılmaktadır. 5 Muharrem 1776/27 Temmuz 1762'de, Midilli adasına yollanacak kerestelerden 60 adet koğuș çamın tanesi kat'iyesiyle birlikte 17 guruș, 190 adet latay-1 kebîrin tanesi ise yine kat'iyesiyle birlikte 22 guruş olmak üzere toplamda 4.550 guruş tutmaktaydı. Kat'iye ve diğer masraflarla 5.971 guruşa ulaşan meblağ Kemer-Edremid'in 242 hanesine bölüştürülmüştü. 1209/1794-95 tarihinde ise yine Midilli'de inşâ olunan bir kalyonda kullanılacak kerestenin katîyesi 2.454, nakliyesi ise 14.586 guruş olmak üzere toplam 17.040 guruş Kemer-Edremid'e tarh edilmişti.1212 /1797-98 tarihli başka bir salyâne defterinde bu kez Midilli ve İstanbul keresteleri için toplamda 2.004 guruşluk kat'iye masrafı mevcuttur.1794-95 tarihli tevzîideki nakliye ücretinin kat'iyeye göre yüksekliği dikkat çekmektedir. (BRHŞS.1094/24-a-1, 46-a-1, 49-b-1)

Kazdağları ve civar yerlerden kesilen kerestelerin sahile indirilmesi gayret gerektiren bir işti. Bilhassa sahile uzak olan kazâlar için meşakkatli bir hizmet hüviyeti kazanıyordu.1305/1888 tarihli Karesi Vilâyet Salnâmesi'ne göre XIX. yüzyılın son çeyreğinde Bigadiç sınırlarında bulunan Ulus Dağı'nın kereste imâl edilen ak ve kara çam türlerini barındırmasına rağmen, kazânın sahile olan uzaklı̆̆ nedeniyle kereste ihraç edilememekte ve üretim iç tüketime yönelik bir șekilde yapılmakta idi. Yine aynı kazadaki Balat nahiyesinde mevcut olan 200.000 dönümlük ala çam ormanı envaî çapta kereste imâline izin veren akçam barındırsa da yine sahile olan uzaklık ve yolların sarplığ 1 gibi sebepler burada keresteciliğin iç piyasaya hitap eden bir sektör olarak gelişmesine neden olmuştu. Salnâmede yer alan ifâdeyle "esbâb-ı naklîyenin fikdânı" yani ulaşım koşullarının yetersizliği kereste ihracâtını önleyen bir sebep olarak karşımıza çıkmaktadır. (Karesi Vilâyetine Mahsûs Salnâme, 1305: s.71-72.)

Ancak körfezde yer alan Edremid, Kemer-Edremid, Ayazmend vs. kazâlar için bilhassa sahile olan uzaklık nedeniyle kereste ihrâcaatı yapılamaması durumu sözkonusu değildi. XIX. yüzyılın sonlarında Kazdağlarının Edremid körfezindeki iskelelere yakınlığı dört ila sekiz saat arasında değişmekte idi. Kazdağları silsilesindeki Atkayası mevkîinin 5-7 saat, Çam Eleği ve diğer kısımların ise iskelelere 10-12 saat arasında bir uzaklığının bulunduğu kaynaklarda zikredilmektedir. Yine Atkayası mevkîi kuzeyde Marmara Denizi kıyısında bulunan Karabiga iskelesine 15-18 saatlik bir mesafedeydi. Kemer-Edremid kazâsındaki Karadere 
mevkîinde 100.000 dönümlük ormanın, sahile uzaklığ 8-10 saat olarak ifade edilmektedir. Ak ve karaçam ağaçlarını barındıran Karadere mevkîinden üretilen keresteler iç tüketime hitap etmekte idi. Bununla birlikte bir su hızarı sayesinde elde edilen mazı ve çam kabuğu civardaki sahillere ihrac ediliyordu. Kereste naklinde kesim mahallinin yakınlığının yanında kolaylık sağlayan diğer bir fizikî avantaj ise imâl edilen yerlerde akarsuların varlığıdır. Karesi Sancağı'nda da mevcut akarsulardan kereste nakli hususunda faydalanılıyordu. (Karesi Vilâyetine Mahsûs Salnâme : 1305 s.75-76, 80; Karabiga iskelesi Edremid körfezindeki kazâlara uzak kabul edildiğinden genelde buraya kereste nakledilmiyordu: "Kemer-Edremid ve Tuzla ve Ezine ve Bayramiç kazaları her ne kadar Karabiga iskelesine semt değil iseler dahi... bu senelik hisselerine isabet eden latay-ı kebir ve koğuş çamın... Karabiga iskelesine nakli-çün”. BRHŞS.1094/85-a-1)

Kereste nakli Batı Anadolu'da genellikle konar-göçer yörük grupları tarafından yapılıyordu. Örneğin Çeşme faciasında batan gemilerin enkazının denizden çıkarılarak gemi yapım bölgelerinden birisi olan Rodos adasına sevki esnasında Saruhan ve Menteşe yöresindeki göçebelerin develerinden yararlanılmıştı. Karesi sahasında yasayan cemaat-i Buğurcular yörükleri de Edremid sahasındaki Kızılcatuzla'dan elde edilen tuzu develeriyle istenen mahallere taşıma ișini üstlenmișlerdi. (Yiğit, 2009: s.121; Köç, 2012: s.60) XIX. yüzy1lın sonlarında Kazdağları yöresinde kereste naklinin yanı sıra imâli de yine konar-göçer gruplardan tahtacı Türkmenler tarafından yapılmaktaydı. Tahtacıların bu işi önceki dönemlerde de yaptıklarına şüphe yoktur. Bizzat kendileri tarafından üretilen bu keresteler, imal bölgelerindeki su hızarları ile kesildikten sonra, merkep ve ester (katır) vasıtasıyla Zeytinli köyündeki mağazalara götürülüyordu. Buradan Edremit kazâsının ana iskelesi konumundaki Akçay İskelesine kereste sevk edildiği gibi, doğrudan doğruya Avcılar ve Ilıca iskelelerine de gönderilebiliyordu. Kazdağlarının öteki yüzünden elde edilen keresteler arabalarla Karabiga iskelesine götürülmekte, oradan da gemilere yüklenerek İzmir, Akdeniz adaları ve diğer adalara nakl olunmakta idi. Biga ve Güvercinlik reayası, camus arabalarıyla Biga-Kemer iskelesine kereste nakl etmekteydiler. Kerestelerin dağlardan kesildikten sonra sahile indirilmeleri sicillerde "ol mikdar keresteyi vusül-i emr-i şerîfimde gönderilen çap ve endazeye muvâfik olarak bir gün evvel cebel-i mezkûreden ka't ve sevahîle nakl" ifadeleriyle belirtilmektedir. (Karesi Vilâyetine Mahsus Salnâme, 1305: s.75; Bostan, 2003: s.114; EŞS.1247/16-a-1) Tespit ettiğimiz bu bilgiler Karesi sancağı ve kazâları açısından kereste ticaretinin önemli bir ekonomik faaliyet olduğunu açıçca göstermektedir. Ayrıca, Kemer-Edremid'den imâl edilen kerestelerin de benzer biçimde konar-göçerler tarafından kesilip iskeleye indirilmesi işleminin incelediğimiz dönemde de yine aynı gruplar tarafından icrâ edildiğine şüphe yoktur.

Zahmetli olduğu kadar belli bir masraf da gerektiren bu iş için gereken öküz, deve, camus vb. yük hayvanları için verilecek ücretler salyâne defterlerine kaydedilerek ahaliden karşılanmaktaydı.Örneğin, Karadeniz sahili ile arasında 4-5 günlük mesâfe olan Sinop dağlarından indirilen bellüt vürdinar cinsi keresteyi taşıyan öküzlerin masrafını reâya karşılayamadığından meblağ ahaliye tevzî edilmişti. Aynı durum Edremit körfezinde yer alan kazâlar için de geçerli idi. Evaîl-i Receb 1247/Aralık başları 1831 tarihiyle Edremit sicillerine kaydedilen bir salyâne defterine göre kerestenin dağdan indirilmesi sırasında telef olan öküzlerin sahiplerine 716 guruş ödenmiştir. Yine aynı hizmeti gören Zeytinli ve Tahtalı karyelerinin masraflarının karşılığı olarak her iki karyeye verilen toplam 567 guruş tevzî defterlerine eklenmişti. (Ünal, 2006: s.240; EŞS.1250/96-a-3.)

Dağlardan büyükbaş hayvanlar gibi çeşitli vasıtalarla kıyıya indirilen keresteler, yüklendikleri gemiler vasıtasıyla iskelelerden gidecekleri mahallere yollanıyorlardı. Kemer-Edremid kazâsınca hazırlanan keresteler kazânın kendi iskelesinden gönderildiği gibi, Edremid iskelelerinden de sevk edilebiliyordu. 10 Zilkâade 1227/17 Ekim 1812 tarihinde Kemer-Edremid'in aynı sene tertibinden bakaya kalan 39.5 kit'a lata ve 80 kıt'a koğuş çam, Akçay iskelesinden Bahr-i Amîk adlı firkateyle gönderilmişti. (BRHŞS.1095-1/10-5, EŞS.1247/54-b-2.) Bu gemileri kullanan reisler arasında memleketleri Kemer-Edremid'in yakın çevresiyle, imparatorluğun farklı bölgelerinden olan kişiler mevcuttu. Ayrıca bazıları müslüman olan bu gemi reisleri ile birlikte zımmîler ve yabancı devlet tebâası kaptanlar da kereste nakledebilmekteydiler. Örneğin yukarıda Mısır donanması için tedariğine izin verildiğinden bahsedilen keresteler, Osmanlı tebâası gayrimüslim bir kaptanın yanı sıra İngiltere, Avusturya ve Rusya devletleri tebâası kaptanların gemileriyle de yollanmıştı. Keresteleri nakleden gemicilerin isim ve taşıdıklanı miktarlar bazı zamanlarda sicillere listeler halinde kaydediliyordu. Bu listelerden kazânın hangi tarihte nereye ne miktar kereste gönderdiği hakkında bilgi 
edinilebilmektedir. 27 Zilkâade 1232/19 Ekim 1816 tarihinde Çanlı Kara Ali reis ve İskenderiyeli Küçük Mustafa reislere ait gemilerle Kemer-Edremid'den 131 koğuş, 71.5 adet latay-1 kebir çam kerestesi Tersâne-i Amireye gönderilmişti. (EŞS.1247/77 a-3, a-4, a-5, a-6, 77-b-1 ,b-2, BRHŞS.1095-1/10-5, EŞS.1247/21-b-4, 1248/21-b-4, b5; Zikredilen bu listelerde Edremit'e bağlı Akçay ve Ilıca iskelelerinden kereste nakl eden gemi kaptanlarının isimleri ve taşıdıkları oranlar hakkında detaylı bilgiler bulunmaktadır. Kemer-Edremid iskelesinden gönderilen keresteler ve bu kerestelerin tahmîl edildiği gemiler ve reîsleri hakkında bir örnek için: Tablo)

\section{Sonuç}

Karesi Sancağı dahilindeki Edremit körfezinde yer alan Burhaniye, XIX. yüzyılın sonlarına kadar KemerEdremid adıyla isimlendirilmiştir. Ülkenin önemli zeytin üreticilerinden olan yakın komşuları Ayvalık ve Edremid ile birlikte Osmanlı başkentinin zeytinyağı ve sabun gibi önemli bazı ihtiyaçlarının karşılanmasına katkı yapmaktaydır. Bunun yanı sıra Anadolu'nun hatırı sayılır orman potansiyeli barındıran mevkîilerinden Kazdağları'nın eteğinde yer alması dolayısıyla, günümüzde de Batı Anadolu'da kereste üretim ve ihraç faaliyetlerinin icrâ edildiği bir yerleşim birimidir. Kazâ ekonomisinin zeytin ile birlikte diğer önemli mamûlü olan kereste, Osmanlı döneminde modern demir ve çelik üretiminin yerleştiği çağa dek, inşâ faaliyetleri hususunda devlet tarafından sık sık ihtiyaç duyulan bir üründü. Osmanlı donanmasını teşkîl eden gemilerin temel malzemesisini teşkîl ettiğinden, karşılanması mühim addedilip bir zorunluluk niteliği kazanmış, ocaklık sistemi dahîlinde düzenli olarak potansiyel sahibi kazâlardan tedârik edilmişti. Bunlardan birisi de Kemer-Edremid idi.

Kemer-Edremid, başkent İstanbul'da mevcut olan Tersâne-i Amire'nin yanı sıra resmî gemi inşâalarının yapıldığı Midilli adası ve Biga-Kemer gibi yakın yerlerde bulunan tezgâhlara kereste yollamaktaydı.Talep edilen gerekli kereste miktarı kazânın hanelerine tevzî edilmekte, aynı zamanda kesim ve nakil esnasında ortaya çıkan g diğer masraflar da bu tevzîilere eklenmekteydi. Resmî makamlarca belirlenen fiyatlara göre alım yapılan keresteler, yörede yaşayan ve bu işle uğraşan reaya tarafından iskelelere indiriliyor, daha sonra gemilere yüklenerek tayîn edilen mahallere gönderiliyorlard1.

Kemer-Edremid, civarındaki tezgâhlara kereste göndermesinin yanı sıra kendi bünyesinde de bir gemi inşâ tezgâhı barındırmaktaydı. Böylece, lojistik kadar, donanma gemilerinin yapımı faaliyetlerine de katkı yapan kazânın bu yönüyle de Osmanlı denizciliği açısından önemli bir rol oynadığı görülmektedir.

Kazânın kereste ile birlikte donanmaya sağladığı diğer bir hizmet, barut yapımında kullanılan güherçile ile birlikte, yine ahşap ürünlerden elde edilen zift ve katran gibi malzemelerin karşılanmasıdır. Yakın komşusu Edremit gibi Kemer-Edremid askerî açıdan önem taşıyan bu yükümlülüğü yerine getirmekteydi. Sefere çıan askerlerin temel yiyeceklerinden birisi olan peksimetin üretilmesi için un gibi gıda maddelerinin hazırlanmasını da aynı kapsamda başka bir önemli katkı sayabiliriz. Malzeme ve iâşe temini gibi hususların yanı sıra, devlet, kazâdan insan kaynakları açısından da çeşitli yükümlülükleri karşılamasını talep etmekteydi. Osmanlı deniz kuvvetlerinin temel askerleri olan kalyoncu neferleri gibi muvazzâf askeri personelin yanı sıra, gemilerde görev yapacak yardımcı askerî sınıflar ve tamir ve inşâ faaliyetlerinde istihdam edilecek kalifiye elemanlar çeşitli tarihlerde istenilen mahallere gönderilmiş̧ti. 


\section{KAYNAKÇA}

\section{ARŞIV BELGELERI}

\section{1.Şeriye Sicilleri}

Burhaniye Şeriye Sicilleri (BRHŞS)

1093,1094, 1095-A, 1095-1

Edremid Şeriye Sicilleri (EŞS)

$1247,1248,1249,1250,1253$

\subsection{Başbakanlık Osmanlı Arşivi (BOA)}

\section{Cevdet Tasnifi (C.)}

Askerîye

nr.403-16655, 465-19419, 667-28028, 1116-49436.

Bahriye

nr.25-1200, 130-6288,136-6584, 145-6957, 195-9155-1.

\section{Meclis-i Valâ (MVL.)}

nr.79-1551

\subsection{Salnâme}


Karesi Vilâyetine Mahsus Salnâme (1305) Balıkesir: Vilâyet Matbâası

Balıkesir Ticaret ve Sanâayi Odası Salnâmesi (1926) İstanbul: Hüsn-i Tabîat Matbâası,

\section{KITAP VE MAKALELER}

AHMED CEVDET PAŞA (1309) Tarih-i Cevdet C.11, İstanbul, Matbâay-1 Osmanîye.

AGOSTON, G. (2006) “Osmanlı İmparatorluğu'nda Barut Sanâayii, XVII. ve XVIII. Yüzyıllarda Selanik, Gelibolu ve İzmir Baruthâneleri” İstanbul: Prof. Mübahat S. Kütükoğlu'na Armağan, Edit. Zeynep Tarım Ertuğ. Bey Matbaâs1.

ALİ CEVAD, (1313) Memalik-i Osmaniye'nin Tarih ve Coğrafya Lügatı C-I, İstanbul: Mahmud

BERKEL, A. (1957) "Kızılçam (Pinus Brutia) da Teknolojik Araştırmalar" İstanbul: İstanbul University Journal Of The Forestry Faculty, Series-A Vol:7, No:1. Yayınları.

BOSTAN, İ. (2003) Osmanlı Bahriye Teşkîlatı: XVII. Yüzyılda Tersâney-i Amîre, Ankara: TTK

BOSTAN, İ. (2004) “Kadırga'dan Kalyon'a”, İstanbul: Osmanlı Araştırmaları- XXIV.

CUINET, V. (2001) La Turquie D’Asie-VII, İstanbul: Les Editions ISIS.

ÇİFTÇI, C. (2000) "Osmanlı Avusturya Savaşları Esnâsında Bursa Halkının Avarız Türü Vergi Yükünden Örnekler” İstanbul: Osmanlı Araştırmaları- XX İstanbul.

EREL, T.L.-ADATEPE, M.F. (2013) “Kazdağı (İda) Jeoarkeolojisine Bir Yaklaşım”, İzmir: The $2^{\text {nd }}$ İnternational Symposium on Kaz Mountains (Mount İda) And Edremit.

ERTUĞ, N. (2001) Osmanlı Döneminde İstanbul Deniz Ulaşımı ve Kayıkçılar, Ankara: Kültür Bakanlığı Yayınları.

HÜLAGÜ, M.(2001) "Osmanlı Devletinde Güherçile Üretimi ve Kayseri Güherçile Fabrikâsı" Kayseri: Erciyes Üniversitesi, Sosyal Bilimler Enstitüsü Dergisi Sayı:11.

GENCER, A.İ. (2001) Bahriye'de Yapılan Islahat Hareketleri ve Bahriye Nezâreti'nin Kuruluşu (1789-1867), Ankara: TTK. Yayınları.

GENÇ,M.(2009) Osmanlı İmparatorluğunda Devlet ve Ekonomi, İstanbul: Ötüken Yayınları.

GENÇ, M. (2009) "Economy And Economy Policy" The Encylopedia Of Ottoman Empire, NewYork: Edit. Gabor Agoston and Bruce Masters, Infobase Publishing.

GENÇ, S. (2013) “XIX. Yüzyılın İlk Yarısında Edremit’te Yabancılar”, Prof.Dr. Mustafa Çetin Varlık Armağanı, İstanbul: KTB Yayınları.

İNALCIK, H. (2011) Devlet-i Aliyye, Osmanlı İmparatorluğu Üzerine Araştırmalar-I, İstanbul: Türkiye İş Bankası Kültür Yayınları.

KILIÇ, O. (2007) “Ocaklık” TDİVA. C-33, İstanbul: Türkiye Diyânet Vakfı Yayınevi. 
KOÇ, B. (2000).“Osmanlı Devleti'ndeki Orman ve Koruların Tasarruf Yöntemleri ve İdarelerine İliş̧in Bir Araştırma" Ankara: Ankara Üniversitesi OTAM Dergisi Sayı-X.

KÖÇ, A. (2012). "Sultan II. Murad Vakfının Edremid Mukatâaları (1530-1641)”, Ankara: Ankara Üniversitesi OTAM Dergisi Say1-XXX.

MANTRAN, R. (1990) 17. Yüzyılın İkinci Yarısında İstanbul C-I, Ankara: TTK. Yayınları.

ÖDEN, Z. G. (1999) Karası Beyliği, Ankara: TTK.Yayınları.

ÖZDEMIR, Ş. (2005) "Osmanlı Donanmasının Bir Seyir Defteri ve XVIII. Yüzyıl Osmanlı Denizciliğine İlişkin Bazı Gözlemler” Ankara: Ankara Üniversitesi DTCF. Tarih Araştırmaları Dergisi, C.24 Say1-37.

PAKALIN, M.Z.(1993) Osmanlı Tarih Deyimleri ve Terimleri Sözlüğü C.II, İstanbul: MEB.Yayınları.

PAYZIN, L. (2003) XVIII. Yüzyılda Midilli Adası, Aydın: Adnan Menderes Üniversitesi Sosyal Bilimler Enstitüsü, Yayımlanmamış Yüksek Lisans Tezi.

POLAT, N.H. (2010) Anadolu ve Suriye'de Seyahât Hatıraları Doktor Şerafeddin Mağmumî, Ankara: Cedit Neşriyât.

ŞEMSEDDİN SAMİ (1314) Kamûs’ül-Alâm C.V, İstanbul: Mihran Matbaası.

TAŞ, K. Z.- İDİGLİ, Z. (2013) “16. Yüzy1l Başında (1515-1516) Edremid'de Meslekler”, İzmir: The $2^{\text {nd }}$ İnternational Symposium on Kaz Mountains (Mount İda) and Edremit.

Vakfi

TEKİN, R.-BAŞ, Y. (2003) Osmanlı Atlası XX. Yüzyıl Başları, İstanbul: Osmanlı Araştırmaları

Türk Deniz Ticareti ve Türkiye Denizcilik İşletmeleri Tarihi C.I, (1994) İstanbul: Türkiye Denizcilik İşletmeleri Kültür Yayınları-I.

UZUNÇARŞILI, İ. H. Büyük Osmanlı Tarihi C.I-II, Ankara: TTK.Yayınları. Yayınları.

UZUNÇARŞILI, İ.H. (1988) Osmanlı Devletinin Merkez ve Bahriye Teşkîlatı, Ankara: TTK.

ÜNAL, M.A. (2006) “XVI. Yüzyılda Sinop Tersânesi İçin Canik Sancağından Malzeme Temini” Samsun: Geçmişten Geleceğe Samsun, Samsun Büyükşsehir Belediyesi Kültür ve Eğitim Hizmetleri Daire Başkanlığı Yayınları.

ÜNAL, M.A. (2011) Osmanlı Tarih Sözlügü, İstanbul: Paradigma Yayınları.

YAKITAL, E. (1995) “Tophânede Döktürülen Fırkâteyn Topları”, İstanbul: Deniz Kuvvetleri Dergisi C.101, Say1-528.

YİĞİT, A. (2009) “165 No’lu Bodrum Şer’iye Sicilinde Bulunan Denizciliğe Ait Kayıtlar”, Muğla: Muğla Üniversitesi Sosyal Bilimler Enstitüsü Dergisi (ILKE) Bahar 2009 Sayı 22. 
Yayinlar1.

YÜCEL, Y.- SEVIM, A. (1989) Türkiye Tarihi-Fetih, Selçuklu ve Beylikler Dönemi, Ankara: TTK.

ZORLU, T. (2008) Sultan Selim III and The Modernisation of Ottoman Navy, New York: Tauris Academic Studies.

\section{EKLER}

BELGE/

BRHŞS 1095-A/7-b-1

Kemer-Edremid Kazâsına Donanma İçin Yapılan Kereste Tevzî

21 Safer 1234 /M. 20 Aralık 1818 

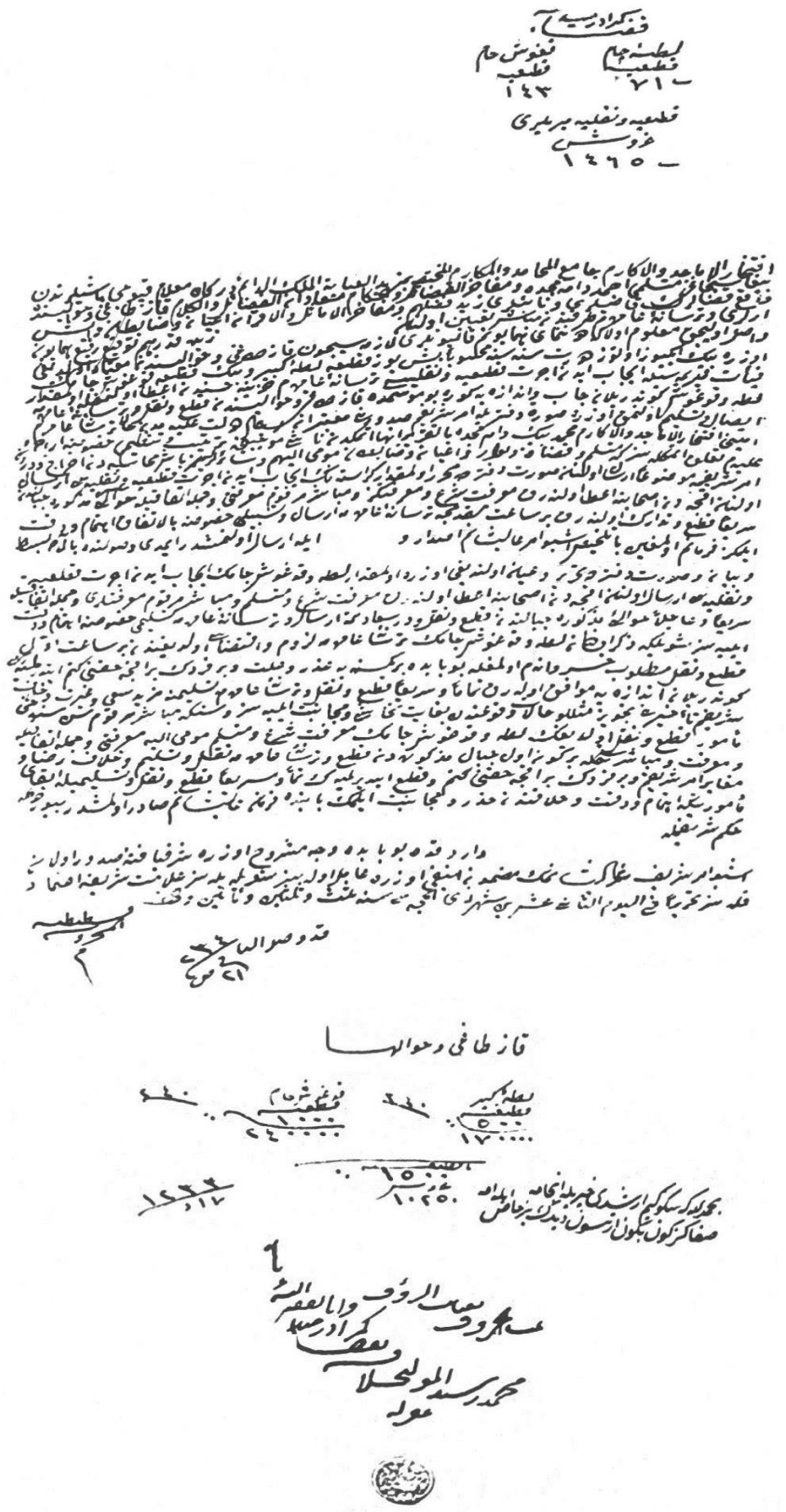

TABLO/

BRHŞS 1094/63-b-3

Kemer-Edremid'den Sefînelerle İstanbul'a Yollanan Keresteler

Ber vech-i balâ Kerestey-i mezkûreden canîb-i Tersâney-i Amîre’ye ceste ve ceste sefîneler ile va'z ve tahmîl olunub irsâl olunan reîslerin ber mûceb-i tahvîl edâ ve esamîleri ve kerestey-i merkûmenin adedi beyânındadır. 


\begin{tabular}{|c|c|c|c|}
\hline Reîs & Tarih & \multicolumn{2}{|c|}{ Kereste- Adet } \\
\hline & & Koğuş & Latâ \\
\hline $\begin{array}{c}\text { Hüseyin Reîs süvâr olduğu sefînesine } \\
\text { vâz ve tahmîl olunan }\end{array}$ & $\begin{array}{l}25 \text { Muharrem } 1215 \\
\text { (18 Hazîran } 1800)\end{array}$ & 53 & 27 \\
\hline $\begin{array}{l}\text { Osman Reîs süvâr olduğu sefînesine } \\
\text { vâz ve tahmîl olunan }\end{array}$ & $\begin{array}{c}5 \text { Safer } 1215 \\
\text { (28 Hazîran 1800) }\end{array}$ & 85 & 53 \\
\hline \multirow[t]{2}{*}{$\begin{array}{l}\text { Hamza Reîs süvâr olduğu sefînesine } \\
\text { vâz ve tahmîl olunan }\end{array}$} & $\begin{array}{l}18 \text { Rebî'ül-ahîr } 1215 \\
\text { (8 Eylül 1800) }\end{array}$ & 118 & 53 \\
\hline & & $\begin{array}{l}\text { Toplam } \\
256\end{array}$ & $\begin{array}{c}\text { Toplam } \\
133\end{array}$ \\
\hline $\begin{array}{l}\text { Gerzeli Hüseyn Reîs süvâr olduğu sefînesine } \\
\text { vâz ve tahmîl olunan }\end{array}$ & $\begin{array}{l}3 \text { Rebî'ül-ahîr } 1216 \\
\text { (13 Ağustos 1801) }\end{array}$ & 158 & 37 \\
\hline ve İstavrozlı Üskübî Reîs Retes? sefînesiyle irsâl & $1216-1801$ & 102 & 43 \\
\hline İskenderiyeli Matye Kapudan süvâr olduğu kalyon-1 limân ile & $1216-1801$ & 61 & 73 \\
\hline & & $\begin{array}{c}\text { Toplam } \\
577\end{array}$ & $\begin{array}{c}\text { Toplam } \\
286\end{array}$ \\
\hline & & \multicolumn{2}{|c|}{$\begin{array}{l}\text { Genel Toplam } \\
\quad 863\end{array}$} \\
\hline \multicolumn{2}{|c|}{ Yalnız sekiz yüz altmış üç kıt’a latâ ve koğuşdur. } & & \\
\hline
\end{tabular}

